No $2006-10$

May

\title{
A Quantitative Assessment of the Outcome of the Doha Development Agenda
}

Yvan Decreux \& Lionel Fontagné 


\section{A Quantitative Assessment of the Outcome of the Doha Development Agenda}

Yvan Decreux \& Lionel Fontagné

No $2006-10$

May 


\section{TABLE OF CONTENTS}

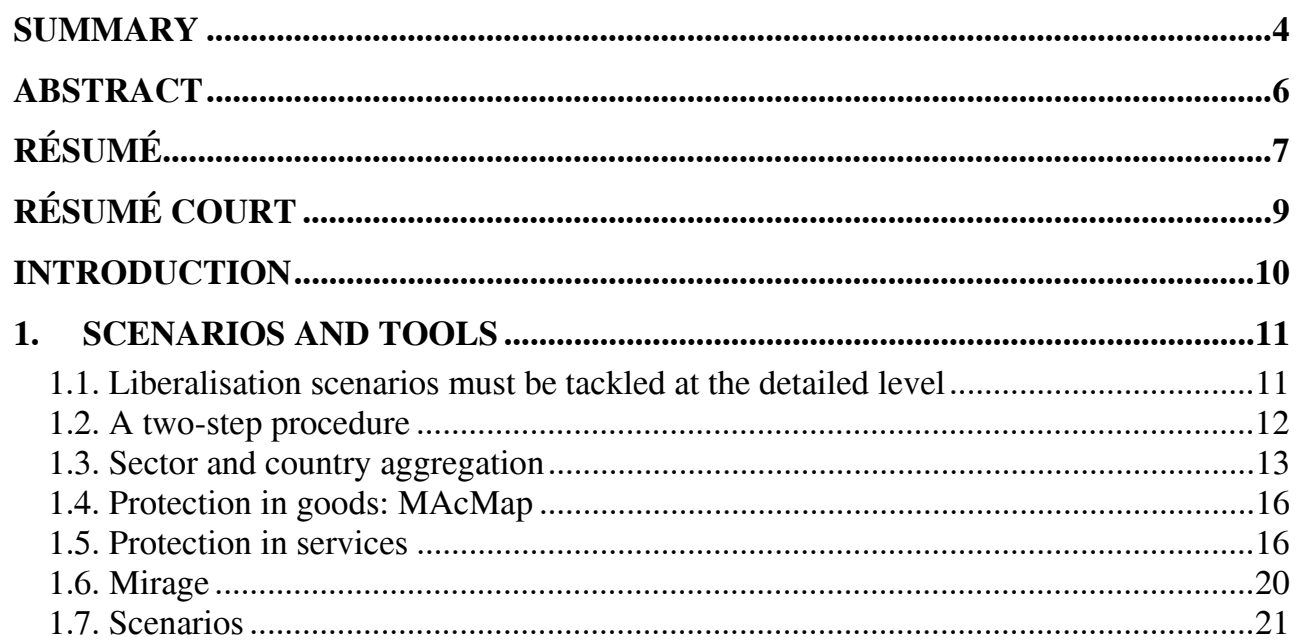

\section{OVERVIEW OF THE GLOBAL IMPACTS OF THE VARIOUS}

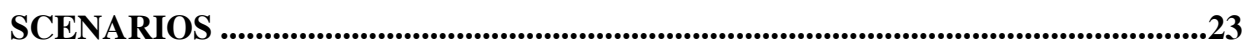

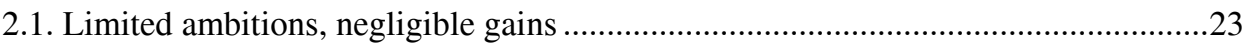

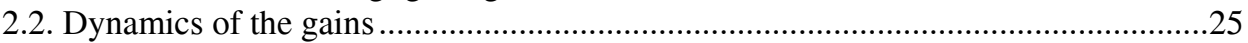

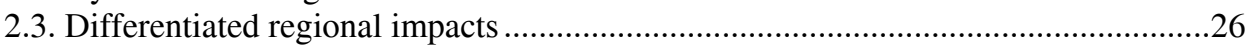

3. LIBERALISING TRADE IN GOODS VERSUS SERVICES ...............................28

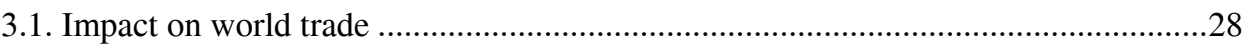

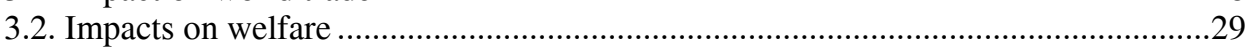

4. DIFFERENTIATED IMPACTS ON THE REGIONS .........................................31

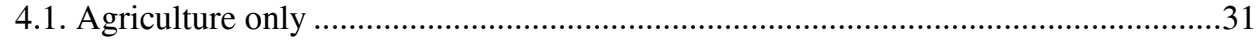

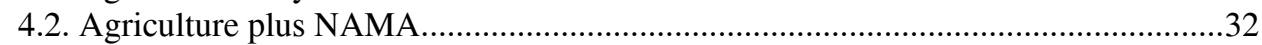

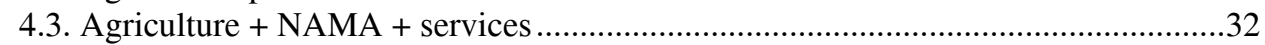

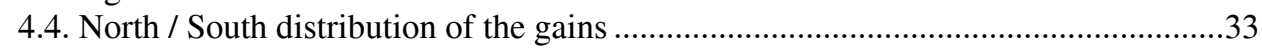

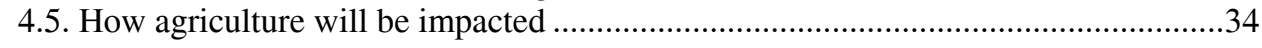

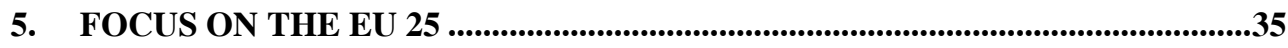

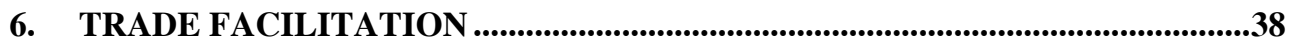

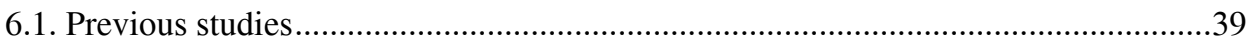

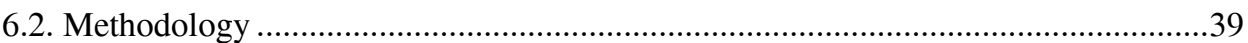

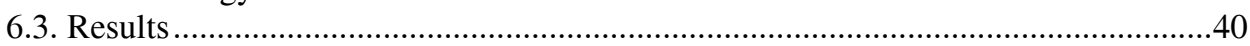

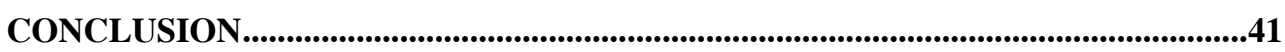

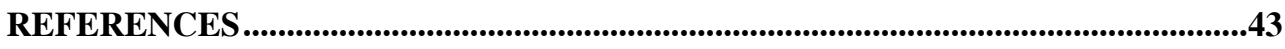

LIST OF WORKING PAPERS RELEASED BY CEPII ........................................46 


\title{
A QUANTITATIVE ASSESSMENT OF THE OUTCOME OF THE DOHA DEVELOPMENT AGENDA
}

\begin{abstract}
SUMMARY
Given the complexity of the negotiation on the Doha Development Agenda (DDA), it is worth relying on a Computable General Equilibrium (CGE) assessment of the different options contemplated by the negotiators, in order to put numbers on the various options. This is done here using the model MIRAGE, the MAcMap database, the GTAP database, existing estimates of protection in the services sector as well as estimates of the administrative and transaction costs to be reduced by trade facilitation measures.
\end{abstract}

We proceed in two steps.

Given the considerable uncertainty as regards the outcome of the negotiation -modalities are still to be finalised - we rely in a first step on scenarios including the basic features of any expected draft agreement, and corresponding to various levels of ambition. One of these scenarios, corresponding to an hypothetical situation of free trade in goods, is devoted to a comparison of our results with other contributions in the literature. The simulations are performed at the most disagreggated level affordable given computational constraints: the world economy is decomposed in 24 regions and 35 sectors.

Then, we implement in a second step repeated simulations in order to better understand the distribution of gains and the respective impacts of the main issues at stake in the negotiations: agriculture, Non-Agricultural Market Access (NAMA), services, trade facilitation. The world economy is then less disagreggated due to computational constraints: 18 regions and 23 sectors.

In all scenarios (with the exception of "free trade"), we consider that the developing economies of the so-called "G90" will not be requested to lower their tariff barriers, nor to cut their eventual domestic support. All tariff reduction are linearly implemented within a three year period for industrialised countries, and a six year one in the developing economies, as a result of the Special and Differential Treatment. In all scenarios export subsidies in agriculture are completely eliminated, taking into account the 2013 deadline agreed in Hong Kong in December 2005. Lastly, domestic farm support is halved in all scenarios; we do consider here that the recent move of the European Union, characterised by a decoupling of internal support launched in January 2006 (according to the June 2003 agreement) is part of the global deal at stake in Geneva. Liberalisation is limited to agricultural and non-agricultural goods in a first place, in order to make comparisons with other studies easier. We then introduce services and trade facilitation.

In scenario A ("standard"), an average 36\% linear cut in tariff in the agricultural sector is implemented, allowing a reduction limited to $25 \%$ for sensitive products (simply defined as the HS6 positions including tariff lines for which a specific tariff is present). As regards the 
NAMA, a 36\% cut is implemented. Limiting this scenario to agriculture leads to scenario Aa.

In scenario B ("ambitious"), a $36 \%$ tariff reduction in agriculture is implemented, but now without exceptions. As regards the NAMA, a Swiss formula based on a $10 \%$ coefficient is implemented. Accordingly, the highest tariffs in industry at the HS6 level are $10 \%$ afterwards. Limiting this scenario to agriculture leads to scenario Ba. A variant is the scenario B2 where the coefficient in the Swiss formula is 15 instead of 10 for developing economies (except G90 ones).

Scenario C ("very ambitious") preserves a differentiated treatment for the developing economies. The tariff reduction in agriculture peaks to $70 \%$ for industrialised economies and $50 \%$ for developing ones. As regards the NAMA, a Swiss formula with respective coefficients of 5\% in the North and $8 \%$ in the South is implemented. Limiting this scenario to agriculture leads to scenario $\mathrm{Ca}$.

Scenario FTG is the free-trade-in-goods benchmark, with zero tariffs and zero subsidy or farm support for all products and countries (including the G90).

In scenario $\mathrm{S} 1$, we introduce a liberalisation of services. The protection in services is reduced by $25 \%$. Here again, countries of the G90 are not expected to liberalise their imports of services. The same percentage of $25 \%$ applies to all other WTO members. The scenarios can be combined (e.g. BS1).

In scenario S2, a removal of $50 \%$ of barriers in services is assumed.

In a last scenario (TF), we apply a successful trade facilitation programme removing all direct and indirect additional trade costs faced when shipping goods to, or from, developing economies, over a ten year period.

As a result of the combination of consolidation margins with existing preferences, and with the lists of exceptions, the actual liberalisation would be extremely limited under scenario A. In total, scenario A should be viewed as a "Round for nothing". At the opposite of the spectrum, free trade in goods would lead to USD 232 bn welfare gains for the world economy (expressed in 2005 terms). Our scenario $C$ just stays in the middle of the road, with half of these gains, while scenario B stands between A and C.

How do these 232 bn welfare gains compare with other estimates? The recent Carnegie report (Polaski, 2006) obtains a 168 bn gain, while gains expected by the World bank (Anderson et al. 2006) peak up to $287 \mathrm{bn}$. These differences are basically due to different sets of assumptions with regards to the adjustment of economies to trade liberalisation shocks. There are also differences in the databases mobilised, but essentially with Carnegie. Regarding tariffs, the current study relies on the same database of applied tariffs than Anderson et al., MAcMap, but also takes into account bound tariffs (consolidated tariff schemes on which the actual tariff cut will be applied). 
When services are introduced in the picture, a very interesting outcome appears: there is more to be gained, for the world economy, from a $25 \%$ cut of the barriers in services, than from a $70 \%$ tariff cut in agriculture in the North, a $50 \%$ cut in the South, and a reduction by half of domestic support, as well as the phasing out of export subsidies.

This is even more true when trade facilitation is taken into account: the gains of scenario B (associated with our less ambitious liberalisation in services) are now more than doubled with trade facilitation. The EU reaps one third of the additional gains, while this is equivalent to doubling official development aid to SSA countries after 2020.

\begin{abstract}
Different options contemplated by the negotiators of the Doha Development Agenda are assessed using the Computable General Equilibrium model MIRAGE, the MAcMap and GTAP databases, existing estimates of protection in the services sector as well as estimates of the administrative and transaction costs to be reduced by trade facilitation measures.

In all scenarios (with the exception of "free trade"), we consider that the "G90" will not be requested to liberalise. Export subsidies in agriculture are completely eliminated, taking into account the 2013 deadline agreed in Hong Kong in December 2005, and domestic farm support is halved.

When an average $36 \%$ linear cut in tariffs is implemented in the industrial and in the agricultural sectors (but with a reduction limited to $25 \%$ for sensitive products in the latter sector), we end up with a "Round for nothing". At the opposite of the spectrum, free trade in goods would lead to USD 232 bn welfare gains for the world economy (expressed in 2005 terms). There is however more to be gained, for the world economy, from a $25 \%$ cut of the barriers in services, than from a $70 \%$ tariff cut in agriculture in the North and a 50\% cut in the South. On the top of this, a successful trade facilitation agenda would be equivalent to doubling official development aid to Sub-Saharan Africa countries after 2020. In the latter case, how to finance such program remains however a challenging issue.
\end{abstract}

JEL classification: D58; F12; F13

Keywords: trade negotiations - computable general equilibrium models - WTO 


\section{UNE QUANTIFICATION DES RÉSULTATS DES NÉGOCIATIONS DU CYCLE DU DÉVELOPPEMENT A L'OMC}

\section{RÉSUMÉ}

Compte tenu de la complexité des négociations du cycle du développement de Doha (DDA), il est utile de s'appuyer sur une évaluation en équilibre général calculable (EGC) des différentes options examinées par les négociateurs, afin de chiffrer les différentes positions. On mobilise à cette fin le modèle MIRAGE, la base MAcMap, la base GTAP, des estimations disponibles des barrières aux échanges dans les services et des ordres de grandeur des coûts de transaction susceptibles d'être réduits à l'occasion d'un programme de facilitation des échanges.

Nous procédons en deux temps.

En raison de l'incertitude entourant les résultats de la négociation - les modalités restent à finaliser - nous nous appuyons dans un premier temps sur des scénarios intégrant les éléments essentiels de tout accord envisageable, pour différents niveaux d'ambition. L'un de ces scénarios, correspondant à une situation hypothétique de libéralisation des échanges, sert de comparaison avec les résultats des autres études, à défaut de constituer une solution réaliste. Les simulations sont réalisées au niveau le plus désagrégé compte tenu des contraintes de calcul: l'économie mondial comprend 24 régions et 35 secteurs.

Dans un second temps, nous procédons à des simulations répétées afin de mieux identifier la distributions des gains et les impacts associés aux différents éléments de la négociation en cours: agriculture, accès aux marchés non-agricoles, services et facilitation des échanges. L'économie mondiale est alors moins désagrégée en raison des contraintes de calcul: 18 régions et 23 secteurs.

Dans tous les scénarios, nous faisons l'hypothèse que les pays en développement du "G90" seront exemptés de toute concession en matière de droits de douane ou éventuellement de soutien interne. Les coupes tarifaires sont réalisés de façon linéaire sur trois ans pour les pays développés, mais six ans pour les pays en développement, en application du principe de traitement spécial et différencié. Dans tous les scénarios les subventions à l'exportation dans l'agriculture sont complètement éliminées, en utilisant l'objectif de 2013 défini à Hong Kong en décembre 2005. Enfin le soutien interne agricole est réduit de moitié dans tous les scénarios: nous considérons que le découplage engagé par l'UE à partir de janvier 2006 (en vertu de l'accord de juin 2003) fait partie des concessions globales accordées par l'UE dans ce cycle. Dans un premier temps on se limite à une libéralisation dans l'agriculture et l'industrie, afin de faciliter la comparaison de nos résultats avec ceux des autres études. La libéralisation dans les services et le programme de facilitation des échanges sont introduits séparément. 
Dans les scénario A ("standard"), une coupe moyenne de $36 \%$ des droits de douane agricole est mise en œuvre, comportant la possibilité de limiter cette réduction à $25 \%$ pour les produits sensibles (simplement définis ici comme ceux pour lesquels existent des droits de douane spécifiques). Concernant l'industrie, une coupe de $36 \%$ est effectuée. On obtient le scénario Aa en limitant ce scénario à l'agriculture.

Le scénario B ("ambitieux"), supprime ce principe des produits sensibles dans l'agriculture, en conservant la coupe moyenne. Une formule suisse est utilisée dans l'industrie, avec un coefficient de 10. Ainsi, aucun droit n'est supérieur à $10 \%$ après application de cette formule. On obtient le scénario Ba en limitant ce scénario à l'agriculture. Une variante est les scénario B2 dans lequel le coefficient est de 15 pour les pays en développement au lieu de 10 (à l'exception de's pays du G90).

Le scénario C ("très ambitieux") maintient ce traitement spécial et différencié pour les économies en développement. La réduction des droits dans l'agriculture est de $70 \%$ pour les pays industrialisés et de $50 \%$ pour ceux en développement. Dans l'industrie, une formule suisse avec des coefficients de 5 au Nord et de 8 au Sud est mise en œuvre. On obtient le scénario Ca en limitant ce scénario à l'agriculture.

Le scénario FTG correspond à un libre-échange, soit la suppression de tous les tarifs, soutiens internes, subventions à l'exportation, pour l'ensemble des secteurs et des pays (G90 compris).

Dans le scénario S1 nous introduisons la libéralisation des services, en réduisant la protection dans ce secteur uniformément de $25 \%$, à l'exception des pays du G90. Les scénarios peuvent être combinés (par exemple BS1).

Dans le scénario S2, les barrières aux échanges de services sont réduites de $50 \%$.

Un dernier scénario concerne la facilitation des échanges: il supprime sur 10 ans les coûts directs et indirects liés aux obstacles additionnels aux échanges de biens avec, ou à partir, des pays en développement.

En raison de la combinaison des marges de consolidation avec les préférences commerciales existantes, et avec les listes d'exceptions, la libéralisation effective serait très limitée dans le scénario A. Au final, ce scénario serait un "Cycle pour rien". A l'autre extrémité, le libre-échange des biens apporterait 232 milliards de dollars (2005) de gains de bien-être à l'économie mondiale. Notre scénario $\mathrm{C}$ est intermédiaire, avec la moitié de ces gains, et le scénario B juste entre A et $\mathrm{C}$.

Ces 232 milliards de gains correspondent-ils aux estimations déjà disponibles? Le récent rapport du Carnegie Endowment for International Peace (Polaski, 2006) obtient 168 milliards, alors que la Banque mondiale a une estimation supérieure: 287 milliards (Anderson et al., 2006). Ces différences sont essentiellement dues à différents ensembles d'hypothèses concernant l'ajustement des économies à la libéralisation commerciale. Les bases de données utilisées différent également, mais essentiellement avec Carnegie. En ce 
qui concerne les tarifs, notre étude et celle de la Banque mondiale s'appuient sur les mêmes données, MAcMap, mais elle prend en compte la différence entre droits de douane appliqués et consolidés.

Lorsque les services sont introduits dans l'analyse, un résultat intéressant apparaît: il y a plus à gagner, pour l'économie mondiale, à une réduction de $25 \%$ des barrières aux échanges de services qu'à une baisse de $70 \%$ des droits de douane dans l'agriculture au Nord $(50 \%$ au Sud), associée à une réduction de moitié du soutien interne et à la suppression des subventions à l'exportation.

C'est encore plus net lorsque l'on introduit la facilitation des échanges: les gains du scénario B (associé à la libéralisation de $25 \%$ des obstacles aux échanges de services), sont alors plus que doublés. L'Union européenne reçoit un tiers de ces gains additionnels, tandis que les gains additionnels pour l'Afrique Sub-Saharienne correspondent à un doublement de l'aide publique.

\section{RÉSUMÉ COURT}

Nous menons une évaluation en équilibre général calculable des différentes issues possibles des négociations du cycle de développement, en utilisant le modèle MIRAGE, les bases de données MAcMap et GTAP, ainsi que les estimations disponibles des barrières réglementaires aux échanges de services et des coûts liés à la question de la facilitation des échanges.

Dans tous nos scénarios (à l'exception du « libre-échange »), nous considérons que les pays du G90 ne prennent pas d'engagement de libéralisation commerciale. Les subventions aux exportations agricoles sont supprimées à l'horizon 2013 conformément à l'accord de Hong Kong de décembre 2005 et le soutien interne à l'agriculture est réduit de moitié.

Une réduction linéaire moyenne de $36 \%$ des droits de douane sur le commerce de marchandises, limitée à $25 \%$ pour les produits agricoles sensibles, déboucherait sur un «Cycle pour rien». A l'opposé du spectre, le libre échange total de marchandises conduirait à 232 milliards de dollars 2005 pour l'économie mondiale. Toutefois, il y aurait plus à gagner à la réduction de $25 \%$ des barrières aux échanges de services, qu'à une baisse de $70 \%$ des droits de douane dans l'agriculture au Nord (50\% pour les pays en développement hors G90). La facilitation des échanges ajouterait des gains considérables, correspondant pour les pays d'Afrique Sub-Saharienne à un doublement de l'aide publique au développement. Concernant ce dernier élément des négociations, la question du financement de la facilitation des échanges reste entière.

Classification JEL: D58; F12; F13

Mots clés: négociations commerciales - modèles d'équilibre général calculable - OMC 


\title{
A QUANTITATIVE ASSESSMENT OF THE OUTCOME OF THE DOHA DEVELOPMENT AGENDA
}

\author{
Yvan DECREUX ${ }^{*}$ - Lionel FONTAGNE ${ }^{\#}$
}

\section{INTRODUCTION}

The Hong Kong Ministerial has paved the way towards a completion of the Doha Development Round, even if numerous technicalities concerning the implementation of the formulas and liberalisation of trade in services remain to be further negotiated.

This complex negotiation has three main characteristics.

First, it involves parties having very different interests in the Round; one could well question whether certain parties, such as small and highly specialised developing economies having to cope with the erosion of their preferences, have any incentive to see this Round completed.

Second, it must lead to a balanced outcome, in terms of liberalisation, between agricultural exporters aiming at opening foreign markets and reducing distorting subsidies, industrial exporters having offensive interests in sectors remaining protected in emerging economies, and countries advantaged in services hoping that the General Agreement on Trade in Services (GATS) will be able to reduce sizeable barriers, of a regulatory nature. There is good evidence however that such conflicts of interest do not match the boundaries of rich versus poor economies. Neither are the traditional groupings such as Cairns still valid. Agricultural exporters may be Least Developed Countries (LDCs) competing against highly subsidised exporters from advanced economies; some "industrial" countries may have an advantage in agriculture; other "industrial countries" may see their advantages shifting towards services; while developing economies such as India may also compete in the latter sector.

Third, this negotiation is highly technical, as "modalities" such as the coefficient in a formula, the percentage of sensitive products, or a given distribution of binding overhang margins, may largely determine the outcome of a given agreement in terms of actual opening of the markets.

All in all, this negotiation is complex enough to legitimate a quantitative assessment tackling simultaneously the three latter elements. It is worth relying on a Computable General Equilibrium (CGE) assessment of the different options contemplated by the negotiators. A CGE will authorise to take into account all relations between markets, prices

\footnotetext{
CEPII, yvan.decreux@cepii.fr

CEPII and Université de Paris I, lionel.fontagne@cepii.fr
} 
and incomes. Such assessment has a big advantage, but also limitations. As regards the pros, this is the only way to shed light on the overall impact of a complex set of decisions in various fields: comparisons of outcomes of the various scenarios will authorise to put simple numbers on complex issues. As regards the cons, a bunch of assumptions are conditioning the results, if not the comparison of the results obtained under alternative scenarios for the same set of assumptions. In order to address the latter difficulty, we will rely on a benchmark authorising the comparison with other studies, we will use rather conservative assumptions, and we will perform repeated simulations in order to better disentangle the respective contributions of the various elements of the negotiation. The target of precisely defining the "modalities" has been missed the $30^{\text {th }}$ April 2006; accordingly we will have to rely on "generic" scenarios including the basic features of any expected draft agreement, and corresponding to various levels of ambition.

The paper is structured as follows. Scenarios and tools are described in Section 1. An overview of the global impacts of the various scenarios simulated with MIRAGE, the CGE Model of the world economy developed by the CEPII, is provided in Section 2. Our horizon is 2020, for a liberalisation beginning in 2007 and following a calendar of (partial) phasing out of trade barriers. The respective contributions of the various pillars of the negotiation are identified in Section 3. The outcome of the negotiation is detailed by region of the world economy in Section 4. A focus on adjustments expected within the EU25 is done in Section 5. The results of the trade facilitation scenario are examined in Section 6. Section 7 concludes.

\section{SCENARIOS AND TOOLS}

\subsection{Liberalisation scenarios must be tackled at the detailed level}

Assessments of the impact of liberalisation are generally carried out using CGE models (see e.g. Francois and Martin, 2004; World Bank, 2003). Among recent noteworthy improvements, Francois and Martin (2004) introduced a refined policy scenario, taken into account a pre-experiment simulation. Building on the work of Walkenhorst and Dihel (2002) aiming at characterising the extent of the binding overhang, Lippoldt and Kowalski (2003) take into account how posted tariff cuts would be reflected in applied tariffs. However, the binding overhang (i.e., the gap between bound and applied duties) is only computed and accounted for at the GTAP sector level, i.e. at a very aggregated sector level. Laird et al. (2003), comparing six proposals were the first ones to compute the corresponding tariff cuts at the detailed level (HS-6), but this was done basically on MFN tariffs: preferential trade agreements were not taken into account, and the binding overhang was not either.

Bouët et al. (2004) incorporate three aspects that are the weak points of most existing models: (i) a precise measurement of protection, including trade preferences, regional agreements, and the gap between applied and bound protection, at a disaggregated product level; (ii) a precise accounting of the complex effects of the various types of domestic support; (iii) a distinction between the various groups of Developing Countries. Their 
estimates of the impact of a Doha agreement on agriculture suggest much lower welfare gains than generally expected. In addition, they identify a large number of developing countries potentially experiencing a loss in welfare, a result that is seldom observed with AGE models. They conclude that the erosion of existing preferences will be an important problem, especially for Sub-Saharan Africa.

Bchir et al. (2005) build on this literature and bring several original contributions as regards the NAMA. Their main contribution lies in the measurement of border protection and in the computation of actual liberalisation resulting from a tariff-cutting formula. Bound and applied duties (whether ad valorem, specific, mixed or compound) are consistently and accurately measured at the HS-6 product level (the most disaggregated level for which harmonised information exists). Accordingly, they are able to account at the same time for trade preferences, for the binding overhang and for the non-linearity of the contemplated Girard formula.

We rely here on a similar approach, extended to integrate in one and the same exercise a liberalisation in agriculture, manufactures and services. Since the available data (in GTAP6 and in MAcMap-HS6) describe the 2001 economy, we first run a "pre-experiment" introducing the changes accruing to the world economy between 2001 and 2005 (accession of China to the WTO for instance). In 2007 (and in the subsequent years, depending on the calendar of phasing out) various scenarios corresponding to the outcome of the DDA are implemented. We finally compare the situation of the world economy in $2007,2008, \ldots$, 2020 , with and without such liberalisation.

\subsection{A two-step procedure}

One striking feature of this kind of exercise is its sensitivity to the level of country and sector aggregation. As a result of the tariffs dispersion between countries within each region, and among categories of products within each sector, relying on more sectors and regions will caeteris paribus lead to larger welfare gains at the world level (the other variables will be basically hardly affected).

This property is a bit unfortunate as policy makers are interested not only in a comparison of outcomes of various scenarios for a given level of aggregation, but also in orders of magnitude of the absolute gains to be expected from trade liberalisation. However, a more disaggregated model comprises a much larger number of equations and raises numerical problems. This is why the bulk of the studies hardly go beyond some 20 regions and 20 sectors when models embody imperfect competition and dynamics.

We will tentatively address this trade-off here by using a two-step approach. In a first step, we try to tackle the absolute gains to be expected from a successful Round, by using the most detailed disaggregation affordable given numerical constraints, as long as imperfect competition and recursive dynamics are introduced. Incidentally, it is not possible to shock the services sectors at this level; the same for trade facilitation. In a second step we implement repeated simulations in order to better understand the distribution of gains and the respective impacts of the different issues at stake in the negotiations: agriculture, 
NAMA, services, trade facilitation. The world economy is then less disaggregated. This is the level where the liberalisation in services and the trade facilitation agenda can be implemented.

\subsection{Sector and country aggregation}

The simulation exercise detailed in the first step, based on an aggregation in 24 regions and 35 sectors, is the frontier of what can be done with a model like Mirage, since one ended up with some 300,000 equations in the model raising very difficult numerical issues. Such model is however not tractable for repeated simulation purposes. Accordingly, repeated simulations as well as liberalisation in services have been performed with less details in the disaggregation, back to a 18 (regions) x 23 (sectors) decomposition of the world economy.

Table 1 reproduces the aggregation of countries into regions, and Table 2 the sector breakdown. In each Table, the second column shows the aggregation adopted in step 1 aiming at identifying the potential gains of an ambitious agenda of liberalisation, and the third column the aggregation adopted in step 2, when repeated simulation and detailed are performed. 
A Quantitative Assessment of the Outcome of the Doha Development Agenda

Table 1: Country aggregation

\begin{tabular}{|c|c|c|c|c|c|}
\hline & 24 (step 1) & 18 (step 2) & & 24 (step 1) & 18 (step 2) \\
\hline Australia & ANZ & ANZ & Austria & EU25 & EU25 \\
\hline New Zealand & & & Belgium & & \\
\hline Rest of & RoW & RoW & Denmark & & \\
\hline Oceania & & & & & \\
\hline China & ChinaHK & ChinaHK & Finland & & \\
\hline Hong Kong & & & France & & \\
\hline Japan & Japan & Japan & Germany & & \\
\hline Korea & Korea & KorTai & United Kingdom & & \\
\hline Taiwan & Taiwan & & Greece & & \\
\hline Rest of East Asia & RoW & RoW & Ireland & & \\
\hline Indonesia & ASEAN & ASEAN & Italy & & \\
\hline Malaysia & & & Luxembourg & & \\
\hline Philippines & & & Netherlands & & \\
\hline Singapore & & & Portugal & & \\
\hline Thailand & & & Spain & & \\
\hline Vietnam & & & Sweden & & \\
\hline Rest of Southeast Asia & & & Cyprus & & \\
\hline Bangladesh & SthAsia & SthAsia & Czech Republic & & \\
\hline Sri Lanka & & & Hungary & & \\
\hline Rest of South Asia & & & Malta & & \\
\hline India & India & & Poland & & \\
\hline Canada & Canada & Canada & Slovakia & & \\
\hline United States & US & US & Slovenia & & \\
\hline Mexico & Mexico & Mexico & Estonia & & \\
\hline Rest of North America & RoW & RoW & Latvia & & \\
\hline Colombia & RoSAm & SthAm & Lithuania & & \\
\hline Peru & & & Switzerland & EFTA & EFTA \\
\hline Venezuela & & & Rest of EFTA & & \\
\hline Rest of Andean Pact & & & Rest of Europe & RoW & RoW \\
\hline Chile & & & Albania & & \\
\hline Rest of South America & & & Bulgaria & Bulg Rom & Bulg Rom \\
\hline Argentina & $\mathbf{A B U}$ & & Croatia & & \\
\hline Brazil & & & Romania & & \\
\hline Uruguay & & & Turkey & Turkey & Turkey \\
\hline Central America & CAm & RoW & Russian Federation & Russia & Russia \\
\hline Rest of FTAA & Caribbean & RoW & Rest of Former Soviet Union & RoW & RoW \\
\hline Rest of the Caribbean & & RoW & Rest of Middle East & & \\
\hline & & & Morocco & NAf & NAf \\
\hline & & & Tunisia & & \\
\hline & & & Rest of North Africa & & \\
\hline & & & South Africa & SthAf & RoW \\
\hline & & & Botswana & SSA & SSA \\
\hline & & & Rest of South African & & \\
\hline & & & Customs Union & & \\
\hline & & & Malawi & & \\
\hline & & & Mozambique & & \\
\hline & & & Tanzania & & \\
\hline & & & Zambia & & \\
\hline & & & Zimbabwe & & \\
\hline & & & Rest of SADC & & \\
\hline & & & Madagascar & & \\
\hline & & & Uganda & & \\
\hline & & & Rest of Sub Saharan Africa & & \\
\hline
\end{tabular}

Note: Bold characters: grouping of countries or regions. 
Table 2: Sector aggregation

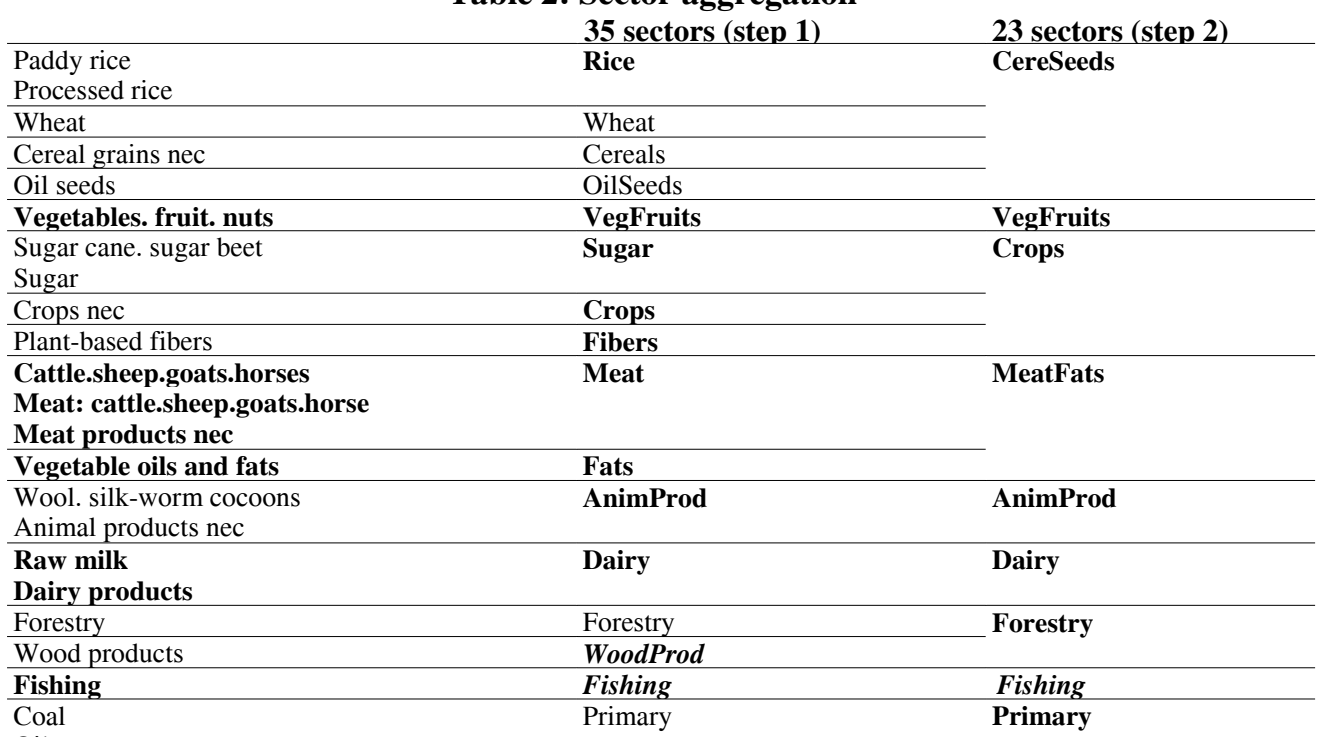

Oil

Gas

Mineral products nec

Minerals nec

Petroleum. coal products

Food products nec

Food

Food

Beverages and tobacco products

Textiles

Wearing apparel

BevTobacco

Leather products

Paper products. publishing

Textile

Textile

Chemical.rubber.plastic prods

Ferrous metals

Paper

Paper

Metals nec

Chemicals

Metal products

MetalProd

Motor vehicles and parts MotorVeh

Transport equipment nec TrspEqNec

Electronic equipment Electronic

Manufactures nec OthManuf

Machinery and equipment nec

Machinery

Electricity

OthSer

Machinery

Gas manufacture. distribution

Water

Construction

Trade

Recreation and other services

PubAdmin/Defence/Health/Educat

Dwellings

\begin{tabular}{|c|c|c|}
\hline Communication & Communic & Communic \\
\hline $\begin{array}{l}\text { Financial services nec } \\
\text { Insurance }\end{array}$ & Fin_Ins & Fin_Ins \\
\hline Transport nec & \multirow[t]{3}{*}{$\operatorname{Tr} T$} & \multirow[t]{3}{*}{$\operatorname{Tr} T$} \\
\hline Sea transport & & \\
\hline Air transport & & \\
\hline Business services nec & BusServ & BusServ \\
\hline
\end{tabular}

Business services nec 


\subsection{Protection in goods: MAcMap}

Based on a joint effort devoted by the International Trade Centre -ITC- (UNCTAD \& WTO, Geneva) and the CEPII to systematically collect detailed and exhaustive information on the level of applied trade barriers, the MAcMap-HS6 database computes an exhaustive and consistent ad-valorem equivalent (AVE) measure of applied protection across the world, at the six-digit level of the Harmonized System (HS-6 level, 5,111 products). 166 reporting countries are covered, with 208 partners, in 2001.

In so doing, the main original contributions of MAcMap-HS6 are: (i) the exhaustive coverage of preferential trade arrangements (PTAs) across the world; (ii) the calculation of the AVE of specific duties, acknowledging the differentiated impact of such duties across exporters, depending on their export unit values; (iii) the incorporation of tariff-rate quotas (TRQs) both through the AVE of the resulting protection at the margin, and through the calculation of involved rents; (iv) an original aggregation methodology, using a weighting scheme based on reference groups of countries, and limiting the extent of the endogeneity bias inherent to the standard, import-weighted average protection.

Here this database is used to construct the scenarios of trade liberalisation at the product level before aggregating the data towards the sectors used in the CGE model. The advantage of such strategy is to fully take into account tariff peaks, exceptions and the possible non linearity of the applied tariff reduction formula, such as the Swiss formula. The advantage of such database to implement a tiered formula in agriculture is obvious. In addition, information on the evolution of quota rents is extracted from the scenario and used in the modelling.

Last but not least, combining this database with information on bound tariffs makes it possible to have a full-fledged representation of the outcomes of any negotiation. WTO agreements use to cut bound tariffs, which leaves applied duties unchanged in many cases, in particular when the gap between initial bound and applied duties is significantly large.

\subsection{Protection in services ${ }^{1}$}

Trade in services faces considerable restrictions, but the assessment of their consequences is not an easy task. They are mostly based on national regulations with a significant trade impact. To introduce them in a quantitative model, it has been necessary to translate them into tariff equivalents.

Tariff equivalents used in this study are based on two different works: Park (2002) and the Australian Productivity Commission (Warren, 2000). They follow two distinct approaches, leading to two quite different sets of values of tariff equivalents. ${ }^{2}$

\footnotetext{
${ }^{1}$ We acknowledge efficient research assistance by Christina Mitaritonna (CEPII) regarding the compilation of barriers in services.
} 
The first approach, followed by Park (2002), is based on a gravity methodology. Park fits a gravity model to bilateral trade in services between 51 countries, considering 7 traded services - Construction, Trade, Transport, Communication, Financial, Business and Others services (Education, Wealth and Administration). The differences between actual and predicted imports are taken to be indicative of trade barriers and then normalised relative to the free-trade benchmarks. The countries with the greatest positive differences between actual and predicted imports are considered to be the free trade "benchmarks" in the regression. The value used as elasticity of substitution is 5.6 for all services sectors.

The second approach is based on a collaborative project. The Productivity Commission and the Australian National University have been measuring restrictions on trade in services for a number of economies in Europe, Asia, and North and South America. The results from this work, the Trade Restrictiveness Index and Price and/or Cost Effect Measures databases, have produced tax equivalents of the price and/or cost effects of restrictions in selected service sectors. More precisely the Trade Restrictiveness index has been calculated for the following 6 services sectors : Telecommunications ${ }^{3}$; Banking ${ }^{4}$; Maritime transport ${ }^{5}$ Education ${ }^{6}$; Distribution ${ }^{7}$; Professional services ${ }^{8}$.

This methodology involves two steps: First, qualitative information about regulations is converted into a quantitative "restrictiveness index"; Second, the effect of this measure of restrictions on prices and/or costs is estimated.

In a first stage, the extent of government regulation of a particular service is quantified using a trade restrictiveness index. Trade restrictiveness indexes summarise the nature and extent of restrictions on trade in services for each economy. Information is collected for each economy on the government regulation of a particular service and classified according to whether the restrictions are i) imposed on establishment or ongoing operations; and ii) non-discriminatory (treat domestic and foreign service suppliers equally) or discriminatory (treat foreign service suppliers differently from (typically less favourably than) domestic service suppliers).

2 These two approaches depart from the one followed by Hoekman (1995), based on frequency measures, and using the GATS commitment schedules of member countries. Hoekman 1) classified these commitments into three categories; 2) assigned a numerical score to each category; 3) computed coverage ratios for each country / sector and 4) proposed a benchmark "guesstimate" of what the tariff equivalent of the less open nation might be, to get a country-specific "tariff-equivalent"..

See Warren (2000b).

${ }^{4}$ See McGuire (1998), McGuire \& Schuele (2000) and Kalirajan et al. (2000).

See Kang (2000)

${ }^{6}$ See Kemp (2000).

See Kalirajan (2000).

See Nguyen-Hong (2000). 
Restrictions on establishment often include licensing requirements for new firms, restrictions on direct investment in existing firms and restrictions on the permanent movement of people. Restrictions on ongoing operations often include restrictions on firms conducting their core business, the pricing of services and the temporary movement of people. Depending on how each of these restrictions apply to domestic and foreign service suppliers, they could be non-discriminatory or discriminatory.

A trade restrictiveness index score is calculated for each economy using a methodology of scores and weights. Restrictions that are common to a number of economies are grouped into restriction categories. Scores are then assigned to each restriction on the basis of a judgement about how stringent it is. The more stringent the restriction, the higher the score. Scores range from 0 to 1 . The restriction categories are then weighted together according to a judgement about their relative economic cost. The weights are generally chosen so that the total restrictiveness index score for an economy ranges from 0 to 1 .

An index score is calculated separately for domestic and foreign service suppliers. A foreign index is calculated to measure all the restrictions that hinder foreign firms from entering and operating in an economy. It covers both discriminatory and nondiscriminatory restrictions. A domestic index represents restrictions that are applied to domestic firms and it generally only covers non-discriminatory restrictions. The difference between the foreign and domestic index scores is a measure of discrimination against foreigners. This discriminatory component will be the only one considered as trade protection in the simulations.

The second step is to enter the restrictiveness index into an econometric model of economic performance in the sector in question (such as price, quantity, price/cost margin, or productivity), along with whatever other factors economic theory suggests might be important determinants of performance (these can be industry specific or economy-wide). Depending on the performance measure chosen, the results provide an indication of the extent to which restrictions affect price-cost margins, and therefore create economic rents, or raise costs above what they otherwise would be in the absence of restrictions. More precisely, the model can be used to predict the "first round" effects of liberalisation (equivalent to the extent of the vertical shift in the supply or demand curve in partial equilibrium analysis) ${ }^{9}$. Mathematical manipulation leads to a percentage "tax equivalent".

Starting from the original data obtained with the two methodologies, two separated data sets are built. In both cases we aggregate original estimations by sector and by country/geographical area, using the value of total demand for this service at market price as a weighting scheme. Data on the demand of services were the one used in the model (GTAP 6).

\footnotetext{
9 Noticeably, a "free trade" benchmark need not always coincide with zero regulation. The method is flexible enough to reckon with the fact that in a free trade situation, it would still be appropriate to have prudential regulation of financial services, safety regulation of air passenger transport services, and so on.
} 
At the geographical level, when no data for a specific country is available, a weighted average of the estimations for the other countries belonging to the same area or all the countries available is used (e.g. as in the case of the Russian Federation). However, when a missing country belongs to a geographical area for which there is original data available we eventually use only original data to compute the average.

Finally, to get the tariff equivalents used in our simulations, we compute a simple average of the values contained in the two comparable data sets.

An example of the data used in our calculations is given for the Banking sector in Table 3, listing the restrictions on commercial presence in banking services.

Table 3: Weights and Scores: Restriction on Commercial Presence in Banking Services

\begin{tabular}{|c|c|c|}
\hline Weight & Score & Restriction Category \\
\hline \multirow[t]{6}{*}{0.20} & & Licensing of banks \\
\hline & 1.00 & Issues no new banking licences \\
\hline & 0.75 & Issues up to three new banking licences with only prudential requirements \\
\hline & 0.50 & Issues up to six new banking licences with only prudential requirements \\
\hline & 0.25 & Issues up to 10 new banking licences with only prudential requirements \\
\hline & 0.00 & Issues new banking licences with only prudential requirements \\
\hline \multirow[t]{2}{*}{0.20} & & Direct investment \\
\hline & & $\begin{array}{l}\text { The score is inversely proportional to the maximum equity participation permitted in } \\
\text { an existing domestic bank. For example, equity participation to a maximum of } 75 \\
\text { percent of a bank would receive a score of } 0.25\end{array}$ \\
\hline \multirow[t]{4}{*}{0.10} & & Joint-venture arrangement \\
\hline & 1.00 & $\begin{array}{l}\text { Issues no new banking licences and no entry is allowed through a joint venture with a } \\
\text { domestic bank }\end{array}$ \\
\hline & 0.50 & Bank entry is only through a joint venture with a domestic bank \\
\hline & 0.00 & No requirement for a bank to enter through a joint venture with a domestic bank \\
\hline \multirow[t]{7}{*}{0.02} & & Permanent movement of people \\
\hline & 1.00 & No entry of executives, senior managers and/or specialists \\
\hline & 0.80 & Executives, specialists and/or senior managers can stay up to one year \\
\hline & 0.60 & Executives, specialists and/or senior managers can stay up to two years \\
\hline & 0.40 & Executives, specialists and/or senior managers can stay up to three years \\
\hline & 0.20 & Executives, specialists and/or senior managers can stay up to four years \\
\hline & 0.00 & $\begin{array}{l}\text { Executives, specialists and/or senior managers can stay for a period of five years or } \\
\text { more }\end{array}$ \\
\hline
\end{tabular}

Source: McGuire and Schuele (2000), op.cit.

10 The Trade sector is documented by Park only. The same for Transport (a sector which is not disentangled in the three sub-sectors of GTAP by the author), Business services, Construction, Recreational, Public and Defence. Communication and Financial services are documented in both studies (see below details on the Banking sector). Insurance is not documented and we apply the data pertaining to the Financial sector. We do not have data for water distribution and hence make the assumption that this sector will not be liberalised. The same for construction. 


\subsection{Mirage}

This Section proposes a brief overview of the CGE model used, namely the MIRAGE model. The main characteristics of the model concern the assumptions made about products quality ranges, imperfect competition, and macro-economic closure.

The demand side is modelled in each region through a representative agent ${ }^{11}$. Domestic products are assumed to benefit from a specific status for consumers, making them less substitutable to foreign products than foreign products between each other. Secondly, products originating in developing countries and in developed countries are assumed to belong to different quality ranges. This is motivated by the fact that several empirical works have shown that unit value differences are able to reveal quality differences even at the most detailed level of products classification. This is likely to have direct consequences on the transmission of liberalisation shocks since the elasticity of substitution is lower across different qualities than across products within a given quality. Hence, the competition between products of different qualities is less tough than between products of similar quality. In the absence of systematic information suitable for incorporation in a worldwide modelling exercise such as the one undertaken here, vertical differentiation is modelled in an ad hoc fashion: developed countries and developing countries are assumed to produce goods belonging to two different quality ranges; substitutability is assumed to be weaker across these two quality ranges, than between products belonging to the same quality range.

As regards the supply side of the model, producers use five factors: capital, labour (skilled and unskilled), land and natural resources. The structure of value added is intended to take into account the well-documented skill-capital relative complementarity. These two factors are thus bundled separately, with a lower elasticity of substitution, while a higher substitutability is assumed between this bundle and other factors.

The production function assumes perfect complementarity between value added and intermediate consumption. The sectoral composition of the intermediate consumption aggregate stems from a CES function. For each sector of origin, the nesting is the same as for final consumption, meaning that the sector bundle has the same structure for final and intermediate consumption.

\footnotetext{
11

The utility function is intra-temporal, with a fixed share of the regional income allocated to savings, the rest used to purchase final consumption. Below this first-tier Cobb-Douglas function, consumption tradeoff across sectors is represented through a LES-CES function. Each sectoral sub-utility function is a nesting of CES functions, comparable to the standard nested Armington-Dixit-Stiglitz function, with two exceptions.

12

Practically, this is modelled by introducing in the demand nesting a tier corresponding to the trade-off between the two quality ranges. This tier is the first one in the consumer choice within each sector, before any other choice in terms of geographical origin.
} 
Constant returns to scale and perfect competition are assumed to prevail in agricultural sectors. In contrast, firms are assumed to face increasing returns to scale (through a constant marginal cost and a fixed cost, expressed in output units) in industry and services. In those sectors, competition is imperfect. ${ }^{13}$ This modelling authorises to capture the procompetitive effect of trade liberalisation.

As regards the markets clearing and the macroeconomic closure, capital good has the same composition whatever the sector, but it cannot change its sector affectation once it has been installed. It is accumulated every year as the results of investments in the most profitable sectors. Natural resources are considered to be perfectly immobile and may not be accumulated. Both types of labour, are assumed to be perfectly mobile across sectors, whereas imperfect land mobility is modelled with a constant elasticity of transformation function. Production factors are assumed to be fully employed; accordingly, negative shocks are absorbed by changes in prices (factor rewards) rather than in quantities. All production factors are immobile internationally. With respect to macroeconomic closure, the current balance is assumed to be exogenous (and equal to its initial value in real terms), while real exchange rates are endogenous.

Since protections in services are regulatory measures leading to no tariff revenue to the importing country, the most adequate way to introduce them was to translate these estimates into export taxes. Liberalising services is therefore expected to lead to large gains for the liberalising countries, whereas gains for the exporting countries are second order ones.

\subsection{Scenarios}

There is considerable uncertainty as regards the outcome of the Doha negotiation. Accordingly, we will rely in what follows on various scenarios including the basic feature of any expected draft agreement, and corresponding to various levels of ambition (Table 4). One of the scenarios, corresponding to an hypothetical situation of free trade, will be used as a benchmark: it allows a comparison of our results with other available studies.

First, we will consider in all scenarios (with the exception of "free trade"), that the members of the G90 are not requested to lower their tariff barriers nor their eventual domestic support. Second, all tariff reduction will be linearly implemented within a three year period for industrialised countries, and a six year one in the developing economies, as a result of the Special and Differential Treatment. Third, in all scenarios export subsidies in agriculture are phased out in 2013. Fourth, domestic farm support is halved in the first three scenarios and eliminated in the "free trade" scenario.

In scenario A, corresponding to a limited level of ambition, an average $36 \%$ cut in tariff in the agricultural sector is implemented. But to do so, we distinguish between sensitive

13 Firms compete à la Cournot, with zero conjectural variations, no Ford effect, and no strategic interaction. Each firm enjoys some market power, and sets its mark-up depending on the extent of product differentiation in the sector, but also of its own market share. 
products (simply defined as the HS6 positions including tariff lines for which a specific tariff is present) and non-sensitive ones. As regards the former, the tariff reduction is limited to $25 \%$, on a linear basis. Tariffs on non sensitive products are reduced by more than $36 \%$ in order to keep the $36 \%$ average. This average is weighted by the number of HS6 positions. This tariff reduction for non sensitive products is however capped to $70 \%$, and the tariff on sensitive products possibly reduced by more than $25 \%$ to keep the $36 \%$ average when this upper limit is reached. As regards the NAMA, a $36 \%$ cut is implemented. Limiting this scenario to agriculture leads to scenario Aa.

In scenario B, less margin of manoeuvre is left to the negotiators as a result of a more ambitious outcome of the Round. A $36 \%$ tariff reduction in agriculture is implemented, without exceptions. As regards the NAMA, a Swiss formula based on a coefficient 10 is implemented. Accordingly, the highest tariffs in industry at the HS6 level are $10 \%$ afterwards. A peculiar feature of this ambitious scenario is the fact that the SDT is limited to a less stringent time frame for implementing the tariff reductions: the percentage cuts are identical for industrial and developing economies (with the exception of the G90, as already mentioned). Limiting this scenario to agriculture leads to scenario Ba. Differentiating the coefficient in the Swiss formula (10 for developed economies; 15 for non- G90 developing economies) leads to scenario B2.

Table 4: The simulated scenarios

\begin{tabular}{|c|c|c|c|}
\hline Scenario & Agriculture & NAMA & Services \\
\hline $\mathbf{A a}$ & \multirow{2}{*}{$\begin{array}{l}\text { Zero export subsidy } \\
\text { Domestic support halved } \\
36 \% \text { tariff cut on average } \\
\text { Sensitive products: } 25 \% \text { cut } \\
\text { Except G90 }\end{array}$} & \multicolumn{2}{|l|}{-} \\
\hline$\overline{\mathbf{A}}$ & & $\begin{array}{l}36 \% \text { tariff cut } \\
\text { Except G90 }\end{array}$ & - \\
\hline $\mathbf{B a}$ & \multirow{6}{*}{$\begin{array}{l}\text { Zero export subsidy } \\
\text { Domestic support halved } \\
36 \% \text { tariff cut } \\
\text { No sensitive products } \\
\text { Except G90 }\end{array}$} & \multicolumn{2}{|l|}{-} \\
\hline B & & \multirow{3}{*}{$\begin{array}{l}\text { Swiss 10 } \\
\text { Except G90 }\end{array}$} & - \\
\hline BS1 & & & $\begin{array}{c}25 \% \text { cut } \\
\text { Except G90 }\end{array}$ \\
\hline BS2 & & & $\begin{array}{c}50 \% \text { cut } \\
\text { Except G90 }\end{array}$ \\
\hline B2S1 & & \multirow[t]{2}{*}{$\begin{array}{l}\text { Swiss } 10 \text { (North) } 15 \text { (South) } \\
\text { Except G90 }\end{array}$} & $\begin{array}{c}25 \% \text { cut } \\
\text { Except G90 }\end{array}$ \\
\hline B2S2 & & & $\begin{array}{c}50 \% \text { cut } \\
\text { Except G90 }\end{array}$ \\
\hline FTG & $\begin{array}{l}\text { Zero export subsidy } \\
\text { Zero domestic support } \\
\text { Zero tariff } \\
\text { Including for G90 }\end{array}$ & $\begin{array}{l}\text { Zero tariff } \\
\text { Including for G90 }\end{array}$ & 然 \\
\hline $\mathrm{Ca}$ & \multirow{2}{*}{$\begin{array}{l}\text { Zero export subsidy } \\
\text { Domestic support halved } \\
70 \% \text { tariff cut (North) } \\
50 \% \text { tariff cut (South) } \\
\text { No sensitive products } \\
\text { Except G90 }\end{array}$} & - & - \\
\hline $\mathrm{C}$ & & $\begin{array}{l}\text { Swiss } 5 \text { (North) } 8 \text { (South) } \\
\text { Except G90 }\end{array}$ & - \\
\hline
\end{tabular}


Scenario $\mathbf{C}$ is very ambitious, but preserves a differentiated treatment for the developing economies. The tariff reduction in agriculture peaks to $70 \%$ for industrialised economies and $50 \%$ for developing ones. As regards the NAMA, a Swiss formula with coefficients of $5 \%$ in the North and $8 \%$ in the South is implemented. Limiting this scenario to agriculture leads to scenario Ba.

Scenario FTG is the free-trade-in-goods benchmark, with 0 tariffs and 0 subsidy or farm support for all products and countries (including for the G90 countries).

In scenario S1, we introduce a liberalisation of services. The protection in services is reduced by $25 \%$. Here again, countries of the G90 are not expected to liberalise their import of services. The same percentage of $25 \%$ applies to all other members of the WTO. The scenarios can be combined (e.g. BS1).

In scenario S2, the removal of 50\% of the barriers in services is assumed. Scenarios S1 and S2 will be combined with scenarios B and B2 (scenarios BS1, BS2, B2S1, B2S2).

In applying the liberalisation formulas in scenarios $\mathrm{A}$ to $\mathrm{C}$, it should be kept in mind that binding overhang and preferences matter, as all cuts are realised on bound tariffs.

\section{OVERVIEW OF THE GLOBAL IMPACTS OF THE VARIOUS SCENARIOS}

\subsection{Limited ambitions, negligible gains}

Every round of trade negotiations under the auspices of the GATT-WTO can be characterised by the level of its ambition.

Our scenario A ("Standard") corresponds to a conservative view of the outcome of the current round, characterised by a limited liberalisation in the agricultural as well as the industrial sectors. Should the outcome of the Doha Round be this "Standard" scenario, WTO member countries would circulate figures corresponding to the average liberalisation in percentage terms pointing out to a "success" (here a 36\% reduction in tariffs). But as a result of the combination of consolidation margins with existing preferences, and with the lists of exceptions, the actual liberalisation would be extremely limited. Devoting so much resources into a several years lasting negotiation involving 148 countries, and generating an additional $1 \%$ of world trade, when world trade is growing at a pace of $8 \%$ annually, should hardly be considered as a success for the international community (Table 5). In total, scenario A should be viewed as a "Round for nothing".

Considering now the other extreme of the spectrum with regards to liberalisation of trade in goods, world trade in agricultural products would be $46 \%$ higher than its current level under a "free trade in goods", a situation meaning free market access, zero export subsidy, zero internal support, and overall world merchandise trade would be $11 \%$ higher. 
Taking the latter hypothetical situation as a benchmark, and not as a policy objective ${ }^{14}$, our scenario $\mathrm{C}$ is indeed a very ambitious one as regards trade in goods, since it allows to cover nearly one fourth of the distance, which would be a very successful outcome for a single Round of negotiations. The "ambitious" scenario, as a result of the combination of binding overhang and SDT hardly increases world trade by $3 \%$.

As regards the NAMA, the big difference is not between scenarios B and C, but between A and $\mathrm{B}$, since the latter replaces the average reduction of $36 \%$ by a Swiss formula having a dramatic impact on tariff peaks.

The impact of the standard scenario on world welfare is negligible. The ambitious scenario doubles these gains, and the very ambitious roughly doubles the latter once again. Accordingly, more ambition will lead to more growth of the world economy. The difference between what is a plausible outcome - "a round for nothing" - and an achievable agreement - such as scenario $\mathrm{C}$ - is worth the negotiation.

How do these results compare with other studies. Using the free trade benchmark, our $0.64 \%$ welfare $(0.67 \%$ GDP) sum up to USD 232 bn, expressed in 2005 terms. This is in line with Anderson et al. (2001) using a static model with perfect competition: 254 bn; as well as Cline (2004): 228 bn; above the Carnegie model addressing unemployment in the South (168 bn), and below the World Bank (287 bn) using a model of the kind of our (dynamic, imperfect competition) but fitted with larger Armington elasticities. Noticeably, the World Bank expresses the gains in 2015 terms, which magnifies the gains: the world economy will be larger by then.

Table 5: Overall impact on trade, GDP and welfare of the four scenarios ( 24 regions $x 35$ sectors, percent deviation from the baseline in 2020 )

\begin{tabular}{|c|c|c|c|c|}
\hline & $\begin{array}{c}\text { A } \\
\text { Standard } \\
\text { (goods) }\end{array}$ & $\begin{array}{c}\text { B } \\
\text { Ambitious } \\
\text { (goods) }\end{array}$ & $\begin{array}{c}\text { Very } \\
\text { ambitious } \\
\text { (goods) }\end{array}$ & $\begin{array}{l}\text { Free trade in } \\
\text { goods }\end{array}$ \\
\hline World Trade (value) & 0.97 & 2.62 & 3.31 & 11.09 \\
\hline World agricultural Exports (value) & 2.79 & 2.91 & 9.56 & 46.01 \\
\hline $\begin{array}{l}\text { World non agricultural Exports } \\
\text { (value) }\end{array}$ & 0.78 & 2.52 & 2.65 & 7.62 \\
\hline World Welfare & 0.09 & 0.18 & 0.33 & 0.64 \\
\hline
\end{tabular}

Source: Author's calculations. *: estimated gains, see text.

To sum up, these overall results strongly reinforce the case for an ambitious and balanced conclusion of the ongoing negotiations. Concluding the Round with only a standard

\footnotetext{
${ }^{14}$ Remember that members of the G90 are also eradicating all their barriers under this hypothesis, whereas they are not asked to participate to the liberalisation process in the three other scenarios.
} 
agreement limited to trade in goods such as the one in scenario A would lead to miss a major opportunity to provide the world economy with additional growth.

These overall results should not hide the various national interests at stake that could hamper progress in the last months of negotiations.

\subsection{Dynamics of the gains}

The dynamics of the impacts of trade liberalisation is very important from a policy point of view. Since opening the economies leads to a new allocation of resources, costs will be faced by certain categories of economic agents in the short run, and it is important for the economy to be able to rapidly reap the benefits of the liberalisation in order to smooth such adjustments. Our simulations point out to gains accruing very rapidly to the world economy. To illustrate this dynamics, let us consider scenario C (Very ambitious in goods) in Figure 1. In 2008, trade in agricultural products is already $8 \%$ higher. At the same date, more than half of the gains in world trade and in world welfare are already secured. Noticeably, while the additional trade impacts are negligible after 2011, world welfare continues to increase steadily up to the term of our simulation exercise: there is still one fourth of the overall welfare gain to be reaped after trade gains are completed.

This is due to the fact that more efficiency leads to more investment and higher growth. In the very long run the steady state will be characterised by the same growth rate as before, but liberalisation provides higher growth during the transitional path leading to a higher level of welfare.

Figure 1: Global gains of trade liberalisation under scenario $C$ (2005-2020, 24 regions $\mathrm{x} 35$ sectors, percent deviation from the baseline - welfare on right scale)

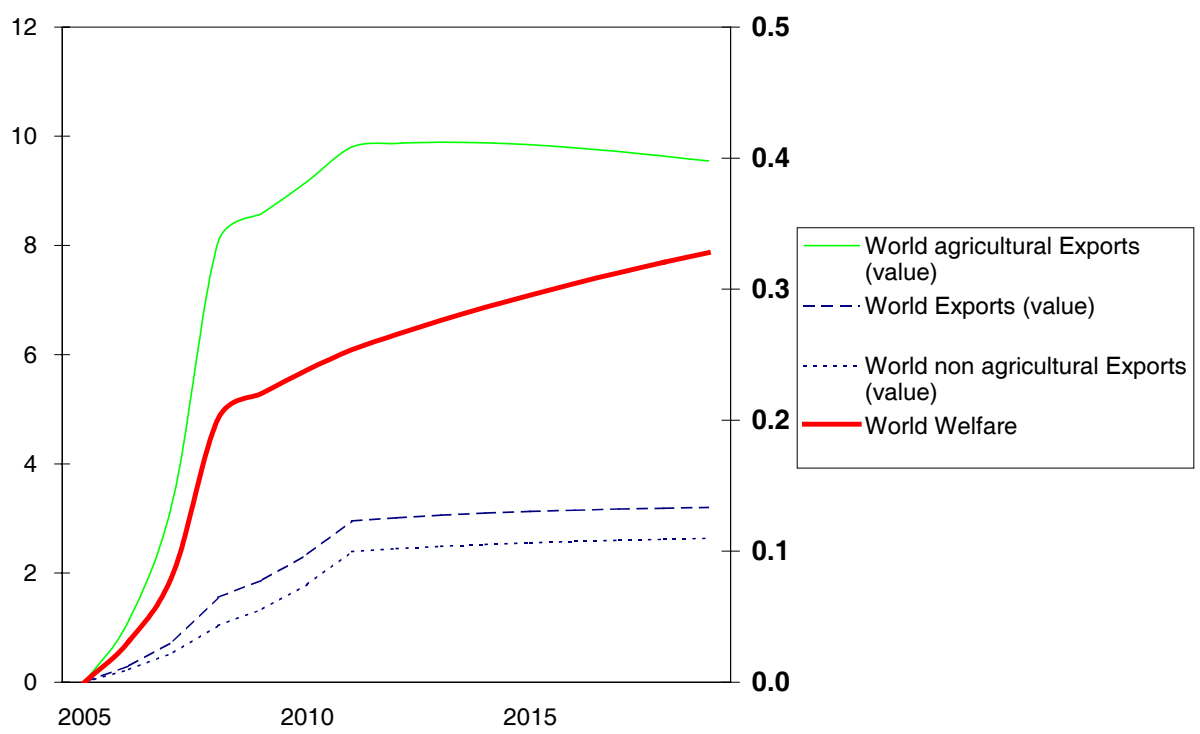

Source : authors' calculations 


\subsection{Differentiated regional impacts}

Not all regions in the world economy will extract the same gains from the Round. Differences in initial specialisation, initial domestic protection, and factor endowment, are leading to contrasted results around the world. This is where a disaggregation of the world economy into 24 regions is worth.

In percentage terms, the largest gains are obtained by the EFTA, thanks to its own liberalisation in agriculture (4.12\% of EFTA's GDP under the very ambitious scenario as compared to $0.04 \%$ under the standard scenario). Then comes Korea (up to $2.27 \%$ ) thanks to its own liberalisation in agriculture and to its offensive interests in the NAMA. ASEAN and Japan are in a similar situation, even if the gains are half those of Korea. In total, Asia is the region that would certainly suffer the most from a collapse of the negotiations, in addition to South Africa. The same conclusion holds for Taiwan, Turkey and India.

Australia and New-Zealand have also large gains to extract from the Round, thanks to their offensive interests in the agricultural sector. Gains accruing to the EU are in the middle of the range (up to $0.36 \%$ ), still very large in absolute terms given the economic size of the region. In contrast, gains for the US economy are limited, while Canada loses.

Then come the difficult situations: the Caribbean would slightly lose to a standard scenario, a situation which is reversed as soon as the Round is increasing its ambitions. The same holds for Russia and Mexico. The frequently raised issue regarding Sub-Saharan Africa, a victim of the erosion of preferences and of the increase in world food prices, is ascertained here. The loss is not negligible under the standard scenario, but it disappears with the increasing ambition of the Round. Last, China will not gain to this Round, since this country has already reaped the benefits of its own liberalisation when acceding to the WTO, and from better access to foreign markets, with the disappearance of textile quotas.

An unexpected outcome is observed for the Latin American countries expected to largely benefit from the liberalisation of the agricultural sector. Here, a deeper liberalisation will eventually translate into more trade, but not necessarily into a higher welfare. The reason for this is the allocation of resources from the increasing returns to scale sector (the manufactures) toward the constant return to scale (agriculture), which is associated with freer trade. However, one should not draw the conclusion that the claims for trade liberalisation of these exporters are firstly motivated by mercantilist views: larger exports and activity in the agricultural sector might alleviate poverty in the rural areas. We will further discuss this issue below.

A different perspective is to look at these results in absolute terms: this replies to the question of how the pie is shared among the participating countries (Table 6). The largest gain (roughly one third of the global gains under scenario C) are accruing to Japan. The EU25 is the second largest region in terms of absolute gains (one fourth of the global gains under scenario C), with USD 32 bn under scenario C, 23 bn. under scenario B and 19 bn. under scenario A. Korea records sizeable gains too, as already noticed. 
Table 6: Welfare gains by region (2020) - 24 regions $x 35$ sectors. Unit: USD bn of 2005

\begin{tabular}{cccc}
\hline & $\mathrm{A}$ & $\mathrm{B}$ & $\mathrm{C}$ \\
\hline Japan & 6.46 & 11.07 & 44.27 \\
EU25 & 19.06 & 23.60 & 32.67 \\
EFTA & 0.18 & 15.08 & 18.95 \\
Korea & 1.13 & 3.04 & 11.14 \\
ASEAN & 1.80 & 5.74 & 7.81 \\
India & 1.57 & 2.43 & 2.70 \\
Australia, Nw Zeald & 1.40 & 1.94 & 2.48 \\
USA & 3.35 & 3.35 & 2.23 \\
Taiwan & 0.70 & 1.49 & 1.84 \\
RoW & $\mathbf{- 0 . 9 3}$ & 0.19 & 1.40 \\
Arg. Brazil, Urug. & 1.77 & 0.97 & 1.24 \\
South Africa & 0.36 & 1.08 & 1.16 \\
Turkey & 0.08 & 0.51 & 0.57 \\
South Asia & 0.06 & 0.43 & 0.43 \\
Mexico & $\mathbf{- 1 . 5 9}$ & 0.21 & 0.42 \\
Russia & $\mathbf{- 0 . 2 7}$ & 0.20 & 0.34 \\
Caribbean & $\mathbf{- 0 . 0 7}$ & 0.21 & 0.33 \\
Central Am. & 0.06 & 0.09 & 0.12 \\
Sub Sah. Africa & $\mathbf{- 0 . 3 7}$ & $\mathbf{- 0 . 2 6}$ & $\mathbf{- 0 . 0 2}$ \\
R o Sth Am. & $\mathbf{- 0 . 0 4}$ & $\mathbf{- 0 . 4 5}$ & $\mathbf{- 0 . 1 2}$ \\
Canada & $\mathbf{- 0 . 8 7}$ & $\mathbf{- 1 . 1 0}$ & $\mathbf{- 0 . 4 7}$ \\
Oth. cand. ctr. & $\mathbf{- 0 . 1 8}$ & $\mathbf{- 0 . 2 1}$ & $\mathbf{- 0 . 5 3}$ \\
North Afr. & $\mathbf{- 0 . 9 6}$ & $\mathbf{- 0 . 9 1}$ & $\mathbf{- 0 . 9 6}$ \\
China HK & $\mathbf{- 0 . 6 1}$ & $\mathbf{- 0 . 7 6}$ & $\mathbf{- 1 . 6 8}$ \\
\hline World & 32.08 & 67.96 & 126.32 \\
\hline
\end{tabular}

Source: Authors' calculations

Welfare changes reported above are the result of various economic effects such as terms of trade changes, allocation gains, changes in rents associated with tariff quotas, etc. Among those effects that will be extensively investigated below, changes in relative prices will translate into changes in terms of trade and hence in welfare. In order to illustrate these changes, we plot in Figure 2, the dynamics of world prices for selected sectors. Clearly, agricultural prices are rising and labour intensive products' prices are diminishing. Depending on the combination of changes in imports and exports structures of the various regions, the impacts may be sizeable: the worst situation is accordingly to import agricultural products, while exporting labour intensive products. How prices change over time in labour intensive industries (electronics, clothing and leather, other manufactured products) is linked to the response of supply to world demand: the very elastic response of supply leads to a decrease in prices after three or four years of liberalisation, whereas other prices continue to increase. 
Figure 2: Prices changes in selected sectors associated with scenario $\mathrm{C}$ ( 24 regions $x 35$ sectors , 2005-2020, percent deviation from the baseline)
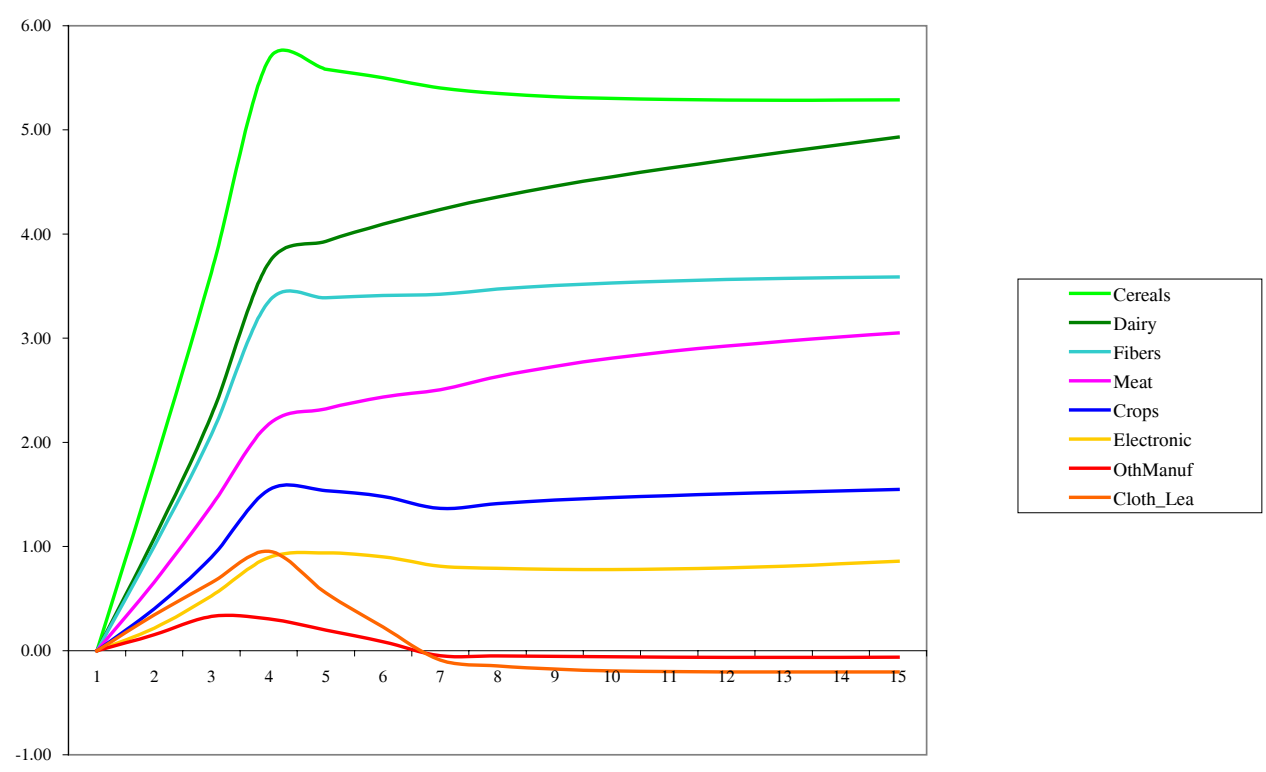

Source : Author's calculations

\section{LIBERALISING TRADE IN GOODS VERSUS SERVICES}

Basically, if one leaves aside the positive impacts of trade facilitation, gains to the world economy may be the result of liberalisation in agriculture, in non-agricultural goods, or in services. What is the contribution of the different pillars to the overall gain, under the various assumptions regarding the ambition of negotiators, will be addressed now. We do so using a 18 regions (plus 2 groupings: North and South) and 23 sectors decomposition of the world economy, as a result of the numerical constraints already stressed.

\subsection{Impact on world trade}

Figure 3 illustrates the impact of trade liberalisation on trade flows under alternative scenarios. Scenarios Aa and Ba have roughly the same and negligible impact on world trade. This is due to the limited impact of these scenarios on trade of agricultural products, and to the limited share of agriculture in total trade. We will see below that trade in certain products is nevertheless largely affected. Scenario B leads to a $2.5 \%$ expansion of world trade, and scenario $\mathrm{C}$ to an additional percentage point. The $25 \%$ cut in obstacles to trade in services translates into 1 percentage point in total world trade, and the $50 \%$ cut has an impact twice as large. Adopting a specific coefficient for developing economies in the Swiss formula, as in scenario B2, reduces world trade by 0.4 percentage point. 
Figure 3: Changes in the value of world exports of goods and services under the various scenarios (18 regions $x 23$ sectors, 2020, percent deviation from the baseline)

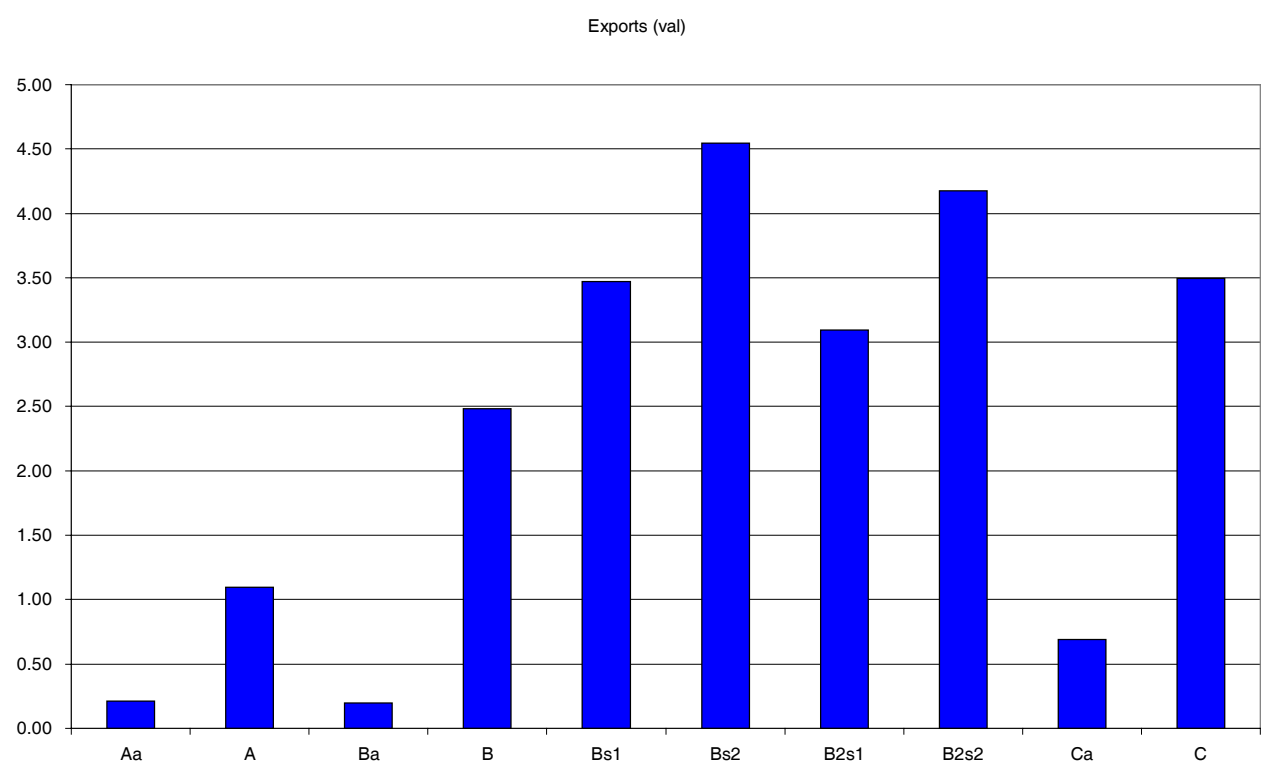

Source: Authors' calculation

\subsection{Impacts on welfare}

How these impacts translate into welfare is illustrated in Figure 4. Whatever the ambition of the Round is for agriculture, the bulk of the gains will be missed if a balanced outcome, integrating an ambitious liberalisation for the NAMA and services is not achieved. 
Figure 4: World-wide welfare gains under various scenarios (18 regions $x 23$ sectors, 2020, percent deviation from the baseline)

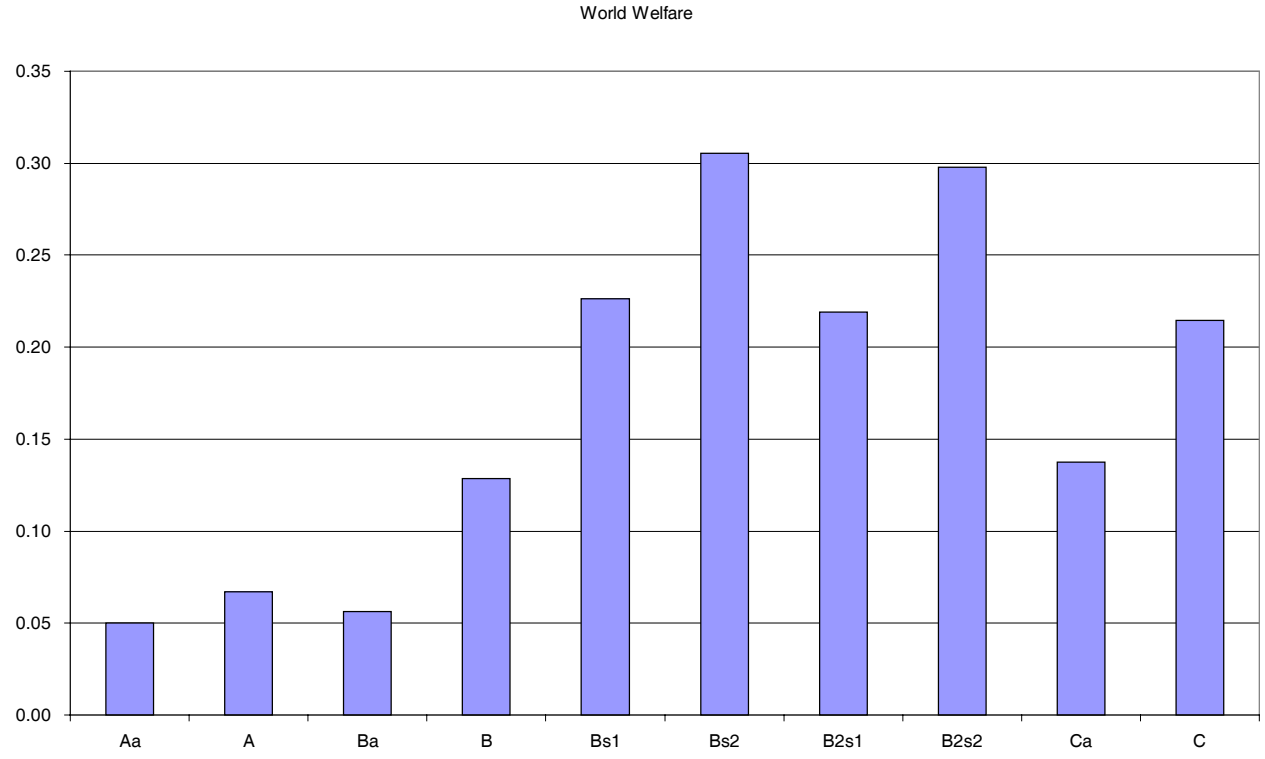

Source: authors calculation

In agriculture, only scenario Ca leads to sizeable gains $(0.14 \%)$. As regards the NAMA, the linear cut of scenario A is worthless: the gain is $0.02 \%$ of world welfare. The Swiss formula in scenario B is much more impacting the world economy, with $0.07 \%$ of world welfare. The same for scenario $\mathrm{C}$ : adopting a specific coefficient in the formula for developing economies does not translate into reduced gains, even if trade is less affected when such solution is adopted. But fundamentally, it must be stressed that a large share of the gains to liberalisation is attributable to services: the gains peak up to $0.30 \%$ of world trade under scenario BS2. Accordingly, cutting $25 \%$ of obstacles to trade in services leads to $0.10 \%$ of welfare at the world level, and respectively $0.18 \%$ for a $50 \%$ cut.

In order to better illustrate this, we can take scenario B and calculate the contributions of the various pillars of the Round to the overall gain under the assumptions of a 25/50\% cut in obstacles to trade in services (Figure 5). Agriculture would contribute to $25 \%$ of the welfare gains at the world level under the assumption of a $25 \%$ cut of obstacles to trade in services, NAMA would contribute to $32 \%$ and services to $43 \%$. The respective contributions would be $18 \%, 24 \%$ and $58 \%$ in the more ambitious scenario as regards services, namely a $50 \%$ cut of trade barriers. 
To put it differently, there is more to be gained for the world economy from a $25 \%$ reduction of barriers in services than from a $70 \%$ tariff cut in agriculture in the North, $50 \%$ cut in the South, a reduction by half of domestic support, and the phasing out of export subsidies.

Figure 5 : Decomposition of welfare gains, under scenarios BS1 and BS2 (18 regions x 23 sectors, 2020, percent deviation from the baseline)

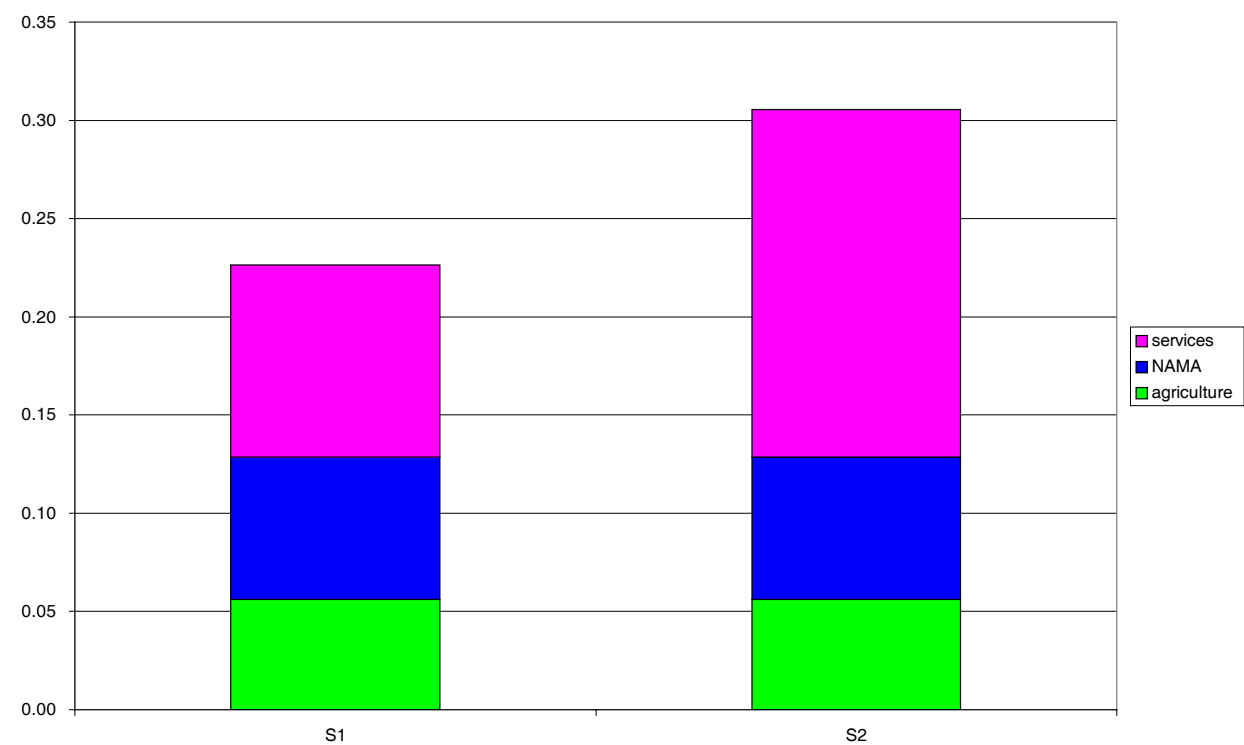

Source: authors calculation.

\section{DIFFERENTIATED IMPACTS ON THE REGIONS}

\subsection{Agriculture only}

A liberalisation limited to agriculture would lead to very unbalanced gains among countries (Table 7). In scenarios $\mathrm{Aa}$ and $\mathrm{Ba}$, the gains are limited to developed importers liberalising their agricultural trade (EFTA, Korea and Taiwan, South Asia and to a lesser extent the EU), and to intermediate income exporters (Australia, New Zealand and South America). In contrast, countries affected by the erosion of preferences and the changes in relative prices would lose (North Africa, Mexico, Sub-Saharan Africa) as well as China. In the most ambitious agricultural scenario, the gains are boosted for highly protective regions in agriculture, such as Korea, Taiwan Japan and EFTA, as well as for food exporters having offensive interests (Australia, New Zealand in particular). 
Table 7: Welfare gains in the 18 regions under various scenarios, 2020 (18 regions $x 23$ sectors, \% deviation from the baseline)

\begin{tabular}{|c|c|c|c|c|c|c|c|c|c|c|}
\hline & A & $\mathrm{Aa}$ & $B$ & B2s1 & $\mathrm{B} 2 \mathrm{~s} 2$ & $\mathrm{Ba}$ & Bs1 & Bs2 & $\mathrm{C}$ & $\mathrm{Ca}$ \\
\hline ANZ & 0.46 & 0.41 & 0.57 & 0.63 & 0.70 & 0.38 & 0.66 & 0.73 & 0.91 & 0.78 \\
\hline ASEAN & 17 & -0.04 & 0.57 & 0.87 & 1.10 & -0.03 & 0.90 & 1.13 & 0.74 & 0.04 \\
\hline Canada & -0.07 & 0.02 & -0.09 & 0.01 & 0.08 & 0.02 & 0.01 & 0.08 & -0.03 & 0.13 \\
\hline $\mathrm{CC} 1$ & -0.23 & -0.17 & -0.36 & -0.33 & -0.35 & -0.16 & -0.32 & -0.34 & -0.44 & -0.04 \\
\hline $\mathrm{CC} 2$ & 0.17 & 0.19 & 0.72 & 0.74 & 0.71 & 0.19 & 0.73 & 0.70 & 0.91 & 0.35 \\
\hline ChinaHK & -0.12 & -0.14 & -0.07 & 0.06 & 0.13 & -0.14 & 0.04 & 0.11 & -0.01 & -0.15 \\
\hline EFTA & 0.01 & 0.01 & 1.47 & 1.59 & 1.69 & 0.00 & 1.61 & 1.71 & 1.94 & 0.44 \\
\hline EU25 & 0.16 & 0.17 & 0.17 & 0.26 & 0.31 & 0.18 & 0.27 & 0.32 & 0.23 & 0.24 \\
\hline Japan & 0.11 & 0.04 & 0.17 & 0.27 & 0.38 & 0.05 & 0.28 & 0.40 & 0.45 & 0.29 \\
\hline KorTai & 0.41 & 0.17 & 0.78 & 0.94 & 1.18 & 0.35 & 1.03 & 1.27 & 1.41 & 0.91 \\
\hline Mexico & -0.18 & -0.06 & 0.13 & 0.14 & 0.21 & -0.04 & 0.21 & 0.28 & 0.13 & -0.01 \\
\hline NAf & -0.45 & -0.41 & -0.45 & -0.71 & -1.02 & -0.40 & -0.69 & -1.00 & -0.38 & -0.32 \\
\hline North & 0.09 & 0.08 & 0.14 & 0.21 & 0.27 & 0.09 & 0.22 & 0.28 & 0.24 & 0.19 \\
\hline RoW & -0.03 & -0.09 & 0.11 & 0.30 & 0.52 & -0.09 & 0.33 & 0.55 & 0.18 & -0.06 \\
\hline Russia & -0.11 & -0.23 & 0.01 & 0.29 & 0.63 & -0.23 & 0.32 & 0.66 & 0.09 & -0.23 \\
\hline & -0.20 & -0.19 & -0.09 & -0.22 & -0.37 & -0.18 & -0.20 & -0.35 & -0.06 & -0.16 \\
\hline SthAm & 0.17 & 0.15 & 0.09 & 0.30 & 0.47 & 0.15 & 0.25 & 0.42 & 0.12 & 0.20 \\
\hline SthAsia & 0.27 & 0.17 & 0.40 & 0.62 & 0.85 & 0.17 & 0.60 & 0.84 & 0.45 & 0.21 \\
\hline South & 0.00 & -0.04 & 0.12 & 0.27 & 0.40 & -0.04 & 0.27 & 0.40 & 0.18 & -0.00 \\
\hline US & 0.02 & 0.03 & 0.02 & 0.06 & 0.10 & 0.02 & 0.06 & 0.10 & 0.02 & 0.04 \\
\hline
\end{tabular}

Source: Authors calculation.

\subsection{Agriculture plus NAMA}

A very different outcome appears when one simultaneously liberalises agriculture and industrial products. Under scenario A, characterised by a lack of ambition, the welfare losses of Sub-Saharan Africa, the Maghreb and China are quite similar. Mexican losses are tripled, due to the loss of preferences in manufactured products in the US market, and a similar outcome is observed for Canada. In contrast, ASEAN losses are now more than compensated by the gains associated with the NAMA. Japanese, Korean and Taiwanese gains are roughly tripled when the NAMA is introduced.

These changes are reinforced under scenario B. The exception is Mexico, for which losses in agriculture are now more than compensated by the NAMA. SSA losses are halved. Under scenario $\mathrm{C}$, the same observations apply. If we can now compare scenarios $\mathrm{A}, \mathrm{B}$ and $\mathrm{C}$, in terms of their percentage gains, with one exception, the most ambitious scenario leads to larger gains or limits the losses.

\subsection{Agriculture + NAMA + services}

Liberalising the service sector has a large impact on world welfare. But interestingly, the impact of such liberalisation on countries is very differentiated. For China, liberalising services is the only source of gains in this Round, as a result of its former liberalisation associated with its accession to the WTO, and of the cancellation of residual quotas in the textile sector. The gains to liberalisation in services are large elsewhere in Asia (in 
particular for the ASEAN, Korea and Taiwan). They are sizeable in South America and in Russia. In Canada, losses are transformed into gains, thanks to the liberalisation in services. An interesting outcome is observed for Sub Saharan Africa and North Africa. These countries do not liberalise their economy and are at the end victims of the liberalisation elsewhere: this shed light on the fact that exempting a large group of WTO members from any liberalisation in a Round is a concession made to these countries that turns perverse. The more ambitious scenario of liberalisation in services reinforces this observation.

\subsection{North / South distribution of the gains}

A contentious issue of the Round is the distribution of welfare gains between the North and the South. Figure 6 stresses that a Round restricted to a liberalisation in agriculture would not favour developing economies taken as a whole, notwithstanding the large gains to be expected by some of them. The South is actually losing under scenarios Aa, Ba, as well as $\mathrm{Ca}$ (only marginally in the latter case). Now, a successful agenda of liberalisation in the NAMA would offer larger gains to the South than to the North, in relative terms, as pointed out by the results for scenarios B and C. In contrast, scenario A would nor lead to any significant gain for the South. This remark is reinforced by the liberalisation in services: the gains peak up to $0.25 \%$ for the South taken as a whole under scenario BS1, and $0.40 \%$ under scenario BS2. Adopting a different coefficient in the Swiss formula for developing economies (scenarios B2S1, B2S2) does not change the picture for the South, and only slightly in the North.

Figure 6: Welfare gains in the North and in the South under the 10 scenarios, 2020 (18 regions $x 23$ sectors, \% deviation from the baseline)

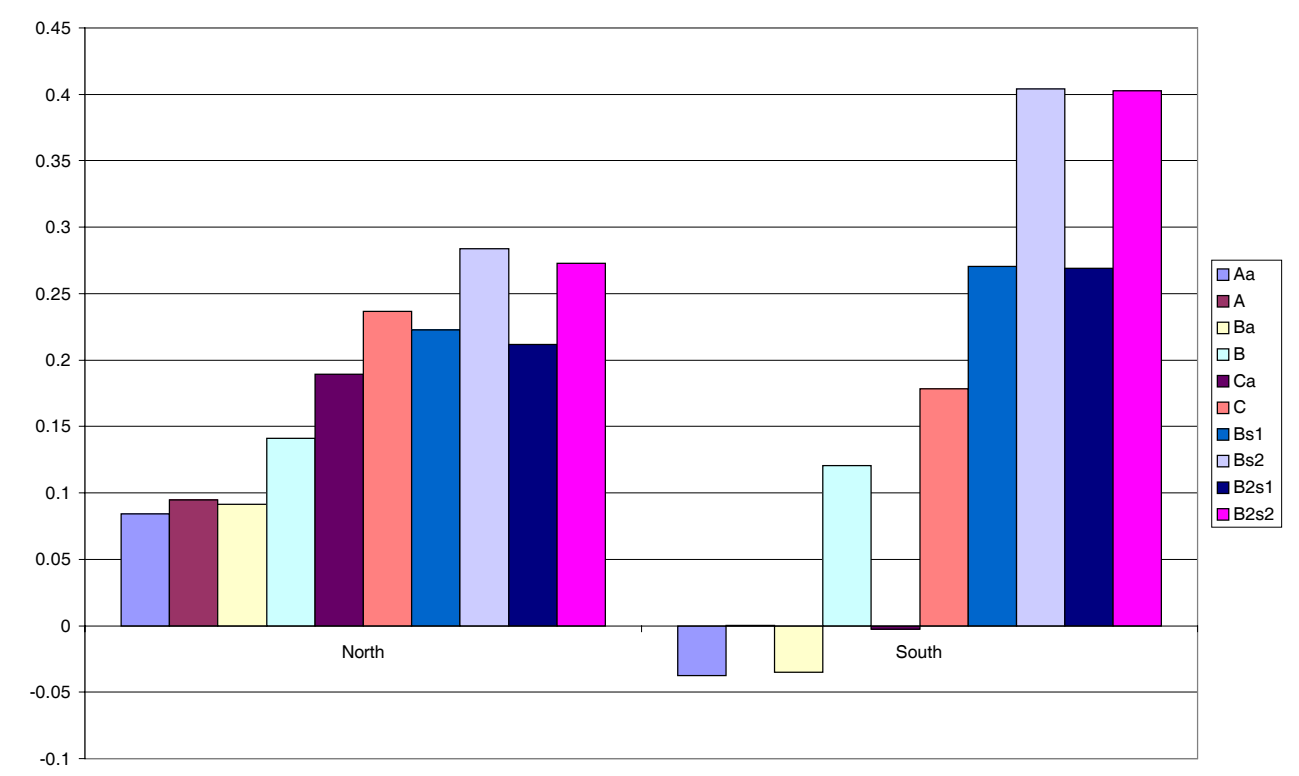

Source: authors calculation 


\subsection{How agriculture will be impacted}

Agriculture has proved to be a very sensitive topic in the negotiations. In particular, there is a concern in Europe and in Japan over a deep cut in production and income; besides, gains might be unevenly shared among developing economies.

We illustrate in Figure 7 the impact on overall employment in agriculture of our 3 scenarios of liberalisation in the sector. Employment losses represent $5.6 \%$ of the labour force employed in the sector under the most ambitious scenario. Such impact is limited in comparison with the trend evolution of the sector in Europe. This evolution is more pronounced in Japan, while jobs are created in the sector in countries having offensive interests (Australia, New-Zealand, Canada, South America). The job creation in the farming sector in Sub-Sahara Africa is the most limited among countries supposed to have a comparative advantage in the sector. The same observation can be made for unskilled wages in agriculture (Figure 8): the loss is limited to $2.6 \%$ under the most ambitious scenario in the EU case. What is very much impacted in contrast is the real return to land, accruing to land owners. The cut corresponds in the EU to $22 \%$ to $24 \%$ of their income depending of the scenario.

Figure 7: Change in employment under 3 scenarios of liberalisation in agriculture (18 regions $\times 23$ sectors, $2020, \%$ deviation from the baseline, selected regions)

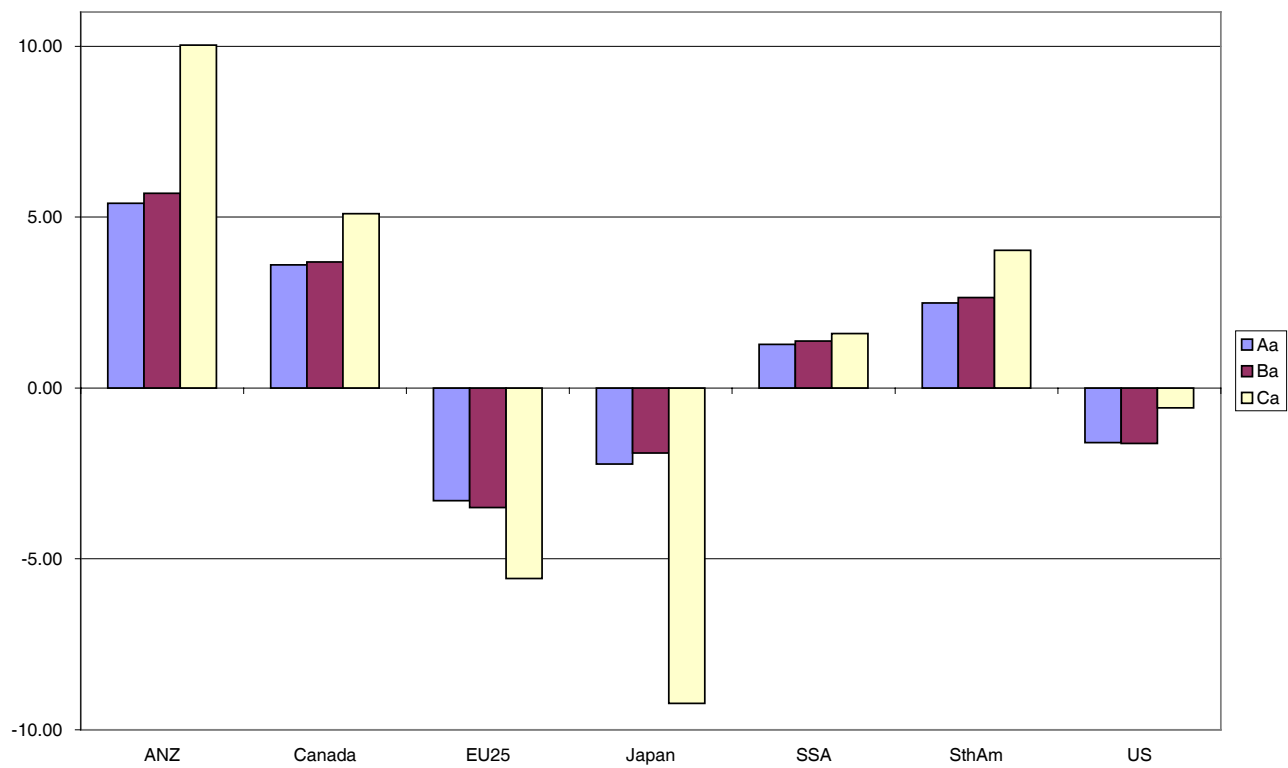

Source: Authors calculation 
Figure 8 : Change in unskilled agricultural wages under 3 scenarios of liberalisation in agriculture (18 regions $x 23$ sectors, $2020, \%$ deviation from the baseline, selected regions)

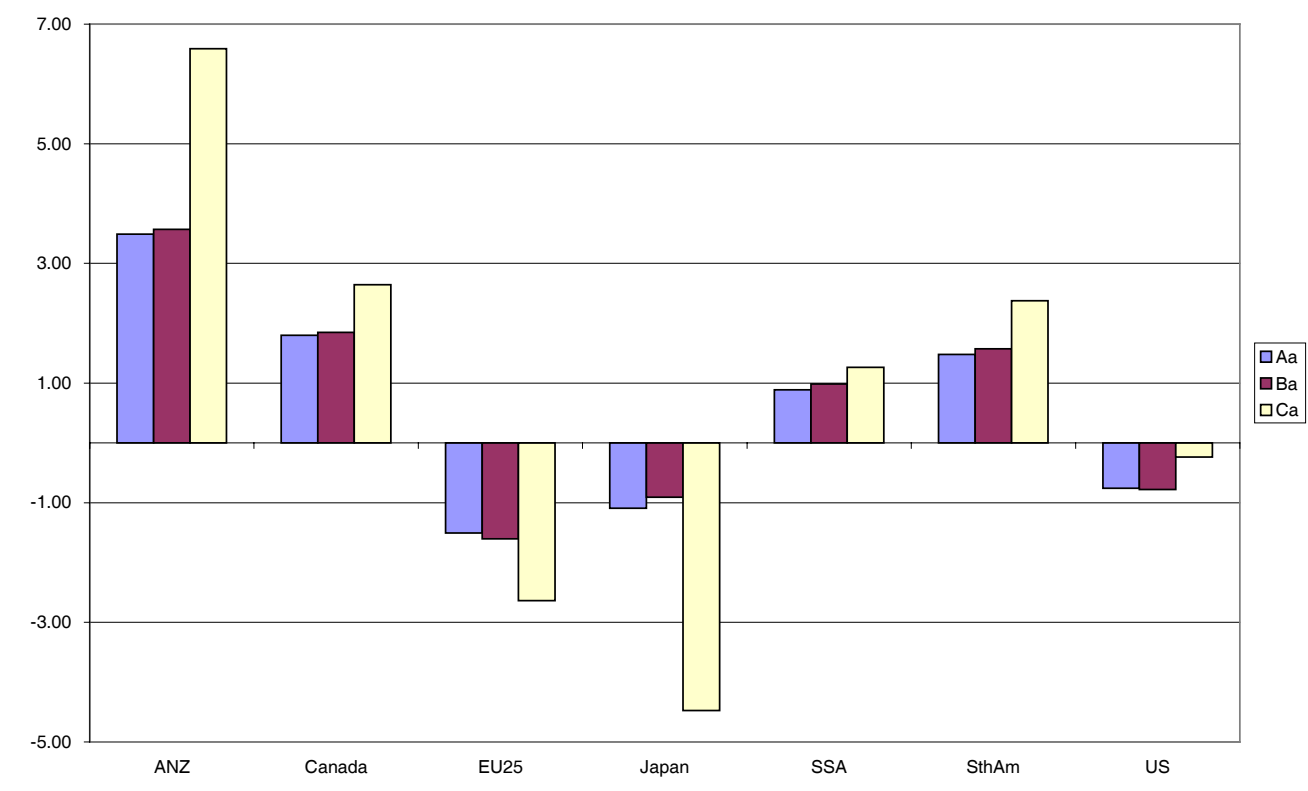

Source: Authors calculation.

\section{FOCUS ON THE EU 25}

Table 8 gives an overview of the changes in 2020 associated with our scenarios, for the main variables of interest and for the EU25. Welfare gains peak up to $0.32 \%$ GDP in scenario BS2. External trade of the EU would increase by more than 5\%, internal trade among member states half less. As a result of the full employment assumption of the model, job losses in agriculture would be compensated by job creations elsewhere in the European economy. In terms of income, skilled workers would be slightly better of $(+0.5 \%$ on average), as well as unskilled workers (resp. $0.25 \%$ ).

This shift of resources between alternative sectors of employment is driven by the very comparative advantages of the EU as well as the highly protected nature of services in numerous economies. An ambitious liberalisation, corresponding to a balanced outcome of the negotiations (scenario BS2) will translate into large increases in (total) exports of services and sizeable cuts in agricultural exports (Figure 9). Exports of business services would record a $15 \%$ increase, transport a $10 \%$ one, financial and insurance services a $8 \%$ one. At the extreme opposite, agriculture will record the largest decreases in exports, with two industrial sectors: textiles and clothing, and electronic equipment and manufactures nec. As regards exports to third countries only, the evolutions are even more dramatic: exports of dairy products are cut by $60 \%$ in value in 2020 , meat and fats by $46 \%$ cereal seeds by $40 \%$ under our central scenario in agriculture (Ba). At the same time, imports of 
business services, other services, crops, transport services, finance and insurance, Meat and fats, and textiles and clothing will increase largely under scenarios B, BS1 and BS2. Scenario C in agriculture leads to a $20 \%$ increase in imports of Crops, and respectively $14 \%$ for Meat and fats.

Table 8 : Change in selected variables for the EU25, selected scenarios (18 regions x 23 sectors, $2020, \%$ deviation from the baseline)

\begin{tabular}{lrrrrrr}
\hline & A & B & Bs1 & Bs2 & B2s2 & C \\
\hline $\begin{array}{l}\text { Employment in agricultural } \\
\text { sectors }\end{array}$ & -3.27 & -3.52 & -3.61 & -3.74 & -3.68 & -5.58 \\
Employment in non & 0.14 & 0.15 & 0.15 & 0.16 & 0.16 & 0.23 \\
agricultural sectors & & & & & & \\
Exports (val_no intra) & 1.24 & 2.04 & 3.67 & 5.47 & 5.24 & 3.82 \\
Exports (val) & 0.10 & 0.27 & 1.35 & 2.52 & 2.44 & 0.56 \\
Imports (val_no intra) & 1.40 & 2.42 & 3.97 & 5.67 & 5.38 & 4.37 \\
Imports (val) & 0.18 & 0.46 & 1.49 & 2.61 & 2.50 & 0.83 \\
Real effective exchange rate & -0.35 & -0.33 & -0.24 & -0.13 & -0.19 & -0.52 \\
Real return to capital & -0.42 & -0.39 & -0.27 & -0.16 & -0.16 & -0.34 \\
Real return to land & -22.71 & -22.88 & -22.98 & -23.17 & -23.14 & -24.39 \\
Real return to natural resources & 0.87 & 1.33 & 1.01 & 0.50 & 0.42 & 1.69 \\
Skilled real wages & 0.42 & 0.44 & 0.55 & 0.58 & 0.56 & 0.59 \\
Tariff revenue (points of GDP) & -0.05 & -0.06 & -0.06 & -0.06 & -0.06 & -0.10 \\
Terms of trade & -0.22 & -0.15 & -0.51 & -0.92 & -0.99 & -0.41 \\
Unskilled real wages & 0.12 & 0.12 & 0.19 & 0.19 & 0.18 & 0.13 \\
Unskilled real wages in & -1.52 & -1.65 & -1.63 & -1.70 & -1.68 & -2.69 \\
agriculture & & & & & & \\
Unskilled real wages in non & 0.20 & 0.20 & 0.27 & 0.27 & 0.26 & 0.26 \\
agricultural sectors & & & & & & \\
Welfare & 0.16 & 0.17 & 0.27 & 0.32 & 0.31 & 0.23 \\
\hline
\end{tabular}

Source: Authors calculation. 
Figure 9: Change in EU25 sectoral exports (value, all destinations) under alternative scenarios (18 regions $\mathrm{x} 23$ sectors, 2020 , \% deviation from the baseline)

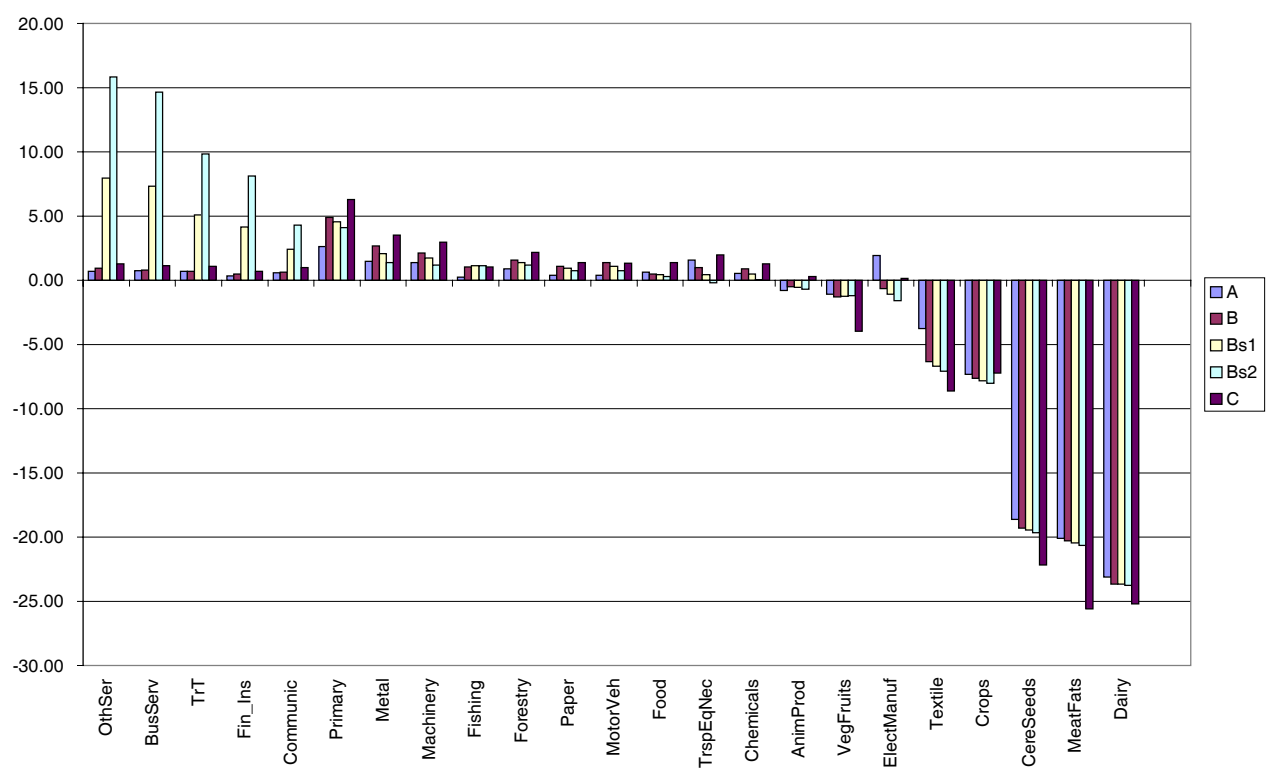

Source: Authors calculation.

These differentiated impacts are thus particularly visible in the agricultural sector, since trade in services increases in both ways. The agro-food production would be cut by $3.2 \%$ under scenarios $\mathrm{Aa}$ and $\mathrm{Ba}$, and by 4.3 under scenario $\mathrm{Ca}$, in the long run in the EU. However, this change will be more pronounced for some categories of producers. The most affected are those producing cereals and seeds: their production will record a $11 \%$ to $16 \%$ decrease, depending on the level of ambition of the scenario. The range is $5 \%-8 \%$ for crops producers, $7 \%-10 \%$ for Meat, Fats and Dairy products, $1 \%-3 \%$ for vegetable and fruits. There will be a slight increase in Forestry, due to land availability.

How jobs will be displaced from one sector to another directly derives from the evolutions referred to above. In (Figure 10) sectors are ranked by decreasing impacts on the value added, and percentage changes of employment in skilled and unskilled labour is shown. The largest losses are in agriculture, in particular for Cereal and seeds, Crops, Dairy products, Animal products, as well as in the textile and clothing sector. These losses correspond to $14 \%$ of the employment of skilled labour and $10 \%$ of unskilled labour in Cereal and seeds, the most impacted sector. One should be aware however that employment in agriculture is limited: accordingly losses expressed in percentage terms are larger than gains in sectors representing a larger share of the European economy such as manufacturing and services. 
Figure 10: Impact of scenario BS1 on job displacements in the EU25 (18 regions $\times 23$ sectors, $2020, \%$ deviation from the baseline)

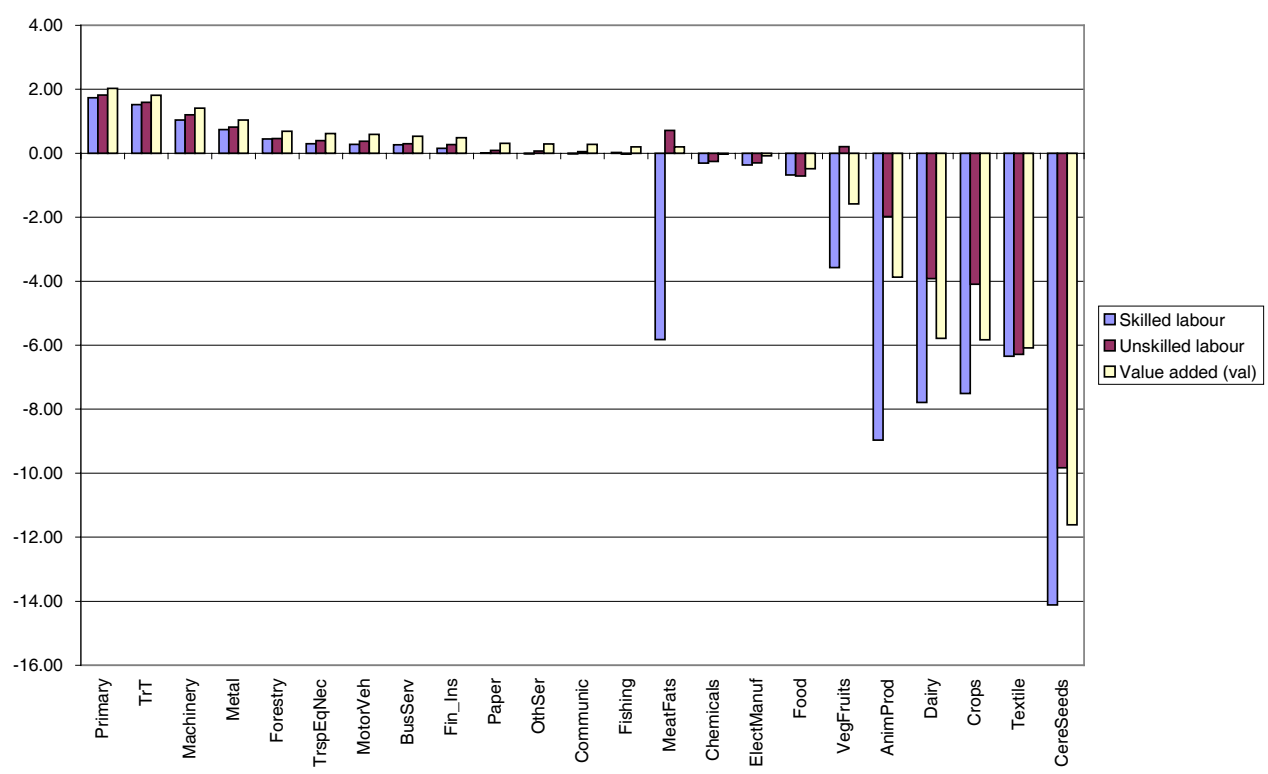

Source: Authors calculation.

\section{TRADE FACILITATION}

An important item of the negotiations is trade facilitation ${ }^{15}$. Two types of trade costs are faced by exporters: direct trade costs (form-fillings and other information and documents to be produced), and indirect trade costs (procedural delays, inventory holding, depreciation of the shipped products, missed business opportunities). The problem is however that no exhaustive analysis of theses costs, direct or indirect, has been made so far. This situation contrasts with the extensive analyses conducted in the past in Europe in the perspective of the completion of the Single Market. The corresponding figures can obviously not be translated at the international level, in particular because the issue at stake mainly concerns developing economies where administrations, infrastructures, as well as governance, are completely different.

${ }^{15}$ We acknowledge helpful suggestions by Priscila Ramos regarding how to tackle this issue in Mirage. 


\subsection{Previous studies}

According to the studies surveyed by the OECD (2002), the direct trade costs are similar for exports and imports and represent an additional $1 \%$ to $15 \%$ of shipping costs. This is a wide range, and the cost faced will depend on the exporter, the importer as well as the sector considered.

Two approaches have been used so far to evaluate the impact of trade facilitation: 1) gravity models regress trade flows on indicators of quality of "trade environment" (e.g. poor efficiency, customs environment, regulatory environment, e-business availability) ${ }^{16}$. 2) CGE modelling has generally proceeded by using the various versions of the GTAP model (static, dynamic, perfect competition, imperfect competition), and reducing evenly trade costs. Trade facilitation is accordingly perceived as a kind of exogenous technical progress. The OECD (2003) as well as Fox et al. (2003) adopt a two tiers approach. Direct costs are considered as logistic duties (export tax plus import tariff), while indirect costs are modelled as an iceberg-type trade cost. The OECD (2003), using the GTAP model, finds that a 1 percent reduction of transaction costs will be associated with USD 40 bn welfare gains at the global level. Francois et al. (2005) using a different model find a USD 72 bn gain as a result of a 1.5 percent reduction in transaction costs. In both studies, gains are accruing mostly to developing economies, in relative terms.

\subsection{Methodology}

We adopt a different approach here. Trade facilitation is modelled as reducing inefficiencies. An iceberg cost is introduced in the model, but there is no export tax and no tariff equivalent of the corresponding cost, hence no associated revenue for the government. An additional variable cost is imposed to producers aiming at acceding to foreign markets For instance, a producer of vegetables will have to ship (and thus to produce) 5\% more, to deliver the same quantity on the destination market, as compared to the domestic market. This may be due to the fact that a part of the shipped products will be corrupted during the customs procedures and delays. This cost is added on the top of transportation costs, tariffs faced abroad etc.

The magnitude of the corresponding variable costs in our exercise is the following, as regards destination markets, for all goods: $2 \%$ in the North, $5 \%$ in the South, $8 \%$ in SubSaharan Africa. We do consider that the $2 \%$ level cannot be compressed, for technical reasons. In addition, SSA countries do face an additional $6 \%$ for their own exports, as a result of poor infrastructures and administration. The exception is agro-food products, where empirical evidence suggest that trade costs are $50 \%$ higher, since perishable foodstuffs are shipped in this case. Accordingly, all coefficients referred to here are multiplied by 1.5 for agro-food products.

${ }^{16}$ See for instance Wilson et al. (2003) and Coulibaly and Fontagné (2006). 
An ambitious scenario of trade facilitation is to overcome all these additional costs progressively over the next decade, in order to reach the incompressible level of $2 \%$ (3\% for foodstuffs) level everywhere. This is a very optimistic scenario, but one can reasonably guess that given the nature of the modelling choices, obtaining only half of this reduction in trade costs would be associated with half of the gains highlighted here. The trade facilitation exercise is performed using as a benchmark our scenario B2S1.

\subsection{Results}

The scenario B2S1 (based on 18x23 decomposition of the world economy) was associated with a $3.1 \%$ increase in world trade (in value); with trade facilitation, this impact is more than doubled and we obtain $7.2 \%$ additional trade. In terms of welfare, the gains are huge too: we obtain an additional $0.95 \%$ of world GDP. To put it differently, trade facilitation is a matter of USD $330 \mathrm{bn}$ at the world level. This is roughly equivalent to the GDP of Russia.

How this enormous potential gain could be shared among participants is clear-cut and confirms the previous studies: the bulk of the gains, in relative terms, are concentrated in the South and in particular in the SSA. It should be stressed that in the latter case, trade facilitation is the only way to obtain a positive outcome of this Round for these countries.

In absolute terms, the size of the economies not surprisingly changes the picture. This is why the EU25 is the region in the world that would benefit the most from trade facilitation (some USD $111 \mathrm{bn}$, what corresponds to one third of the overall gains at the world level). Anyway, some USD 20 bn would accrue to SSA countries. This is to be compared with the ODA received by the region (USD 18.6 bn on average in 2003 and 2004). In the same region, this would be associated with a $9.2 \%$ increase in unskilled real wage, hence contributing to the alleviation of poverty.

It has to be stressed that we did not introduce any cost of implementing such trade facilitation, due to a lack of data regarding this cost. Accordingly, how the large investments needed to achieve such improvements of the trade environment remains an open issue. However, considering the huge gains to be expected, there is no doubt that it would be worth the costs. 
Figure 11: Welfare gains under scenario B2S1 with and without trade facilitation (18 regions $\mathrm{x} 23$ sectors, $2020, \%$ deviation from the baseline)

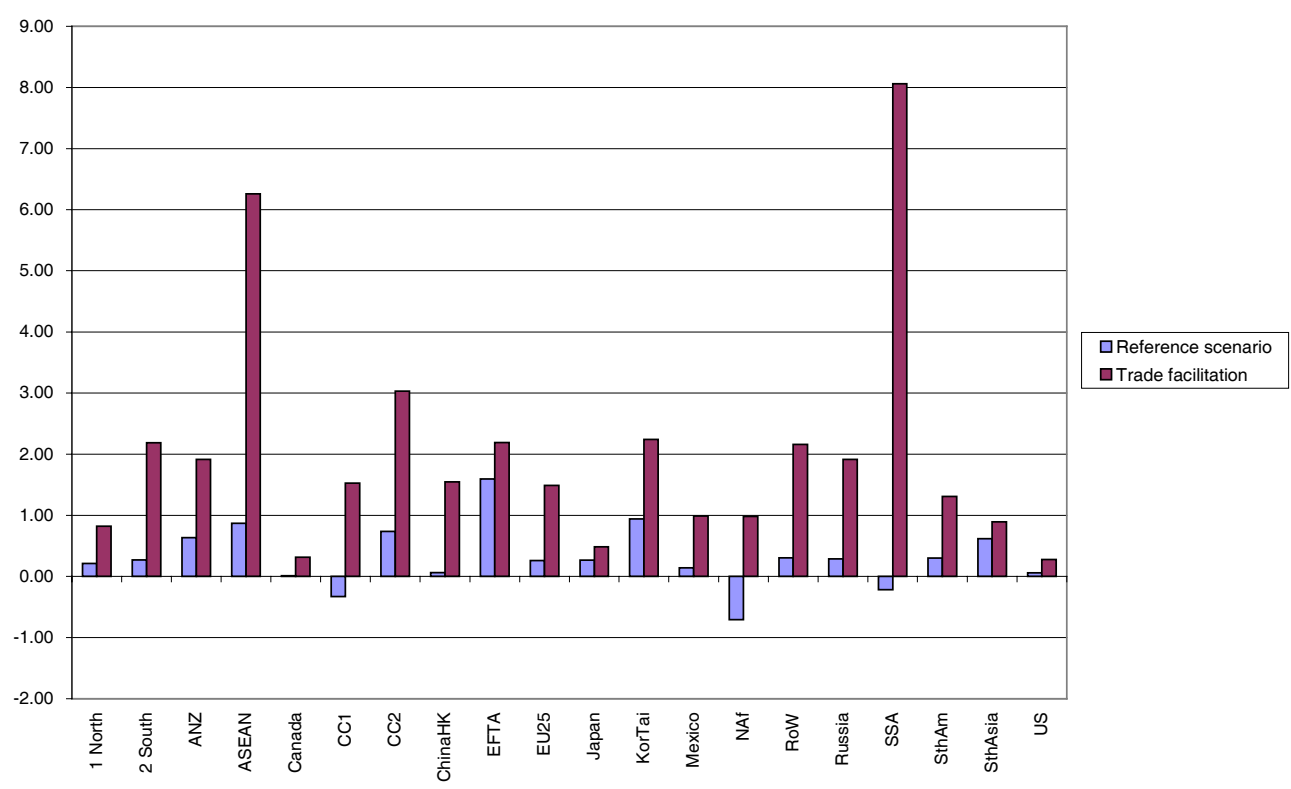

Source: Authors calculation.

\section{CONCLUSION}

The Hong Kong Ministerial has paved the way towards a completion of the Doha Development Round. Given the complexity of the negotiation, it is worth relying on a CGE assessment of the different options contemplated by the negotiators in order to put numbers on the various options.

We have considered in all scenarios (with the exception of "free trade"), that the members of the G90 will not be requested to lower their tariff barriers nor their eventual domestic support. All tariff reduction have been linearly implemented within a three year period for industrialised countries, and a six year one in the developing economies, as a result of the Special and Differential Treatment. In all scenarios export subsidies in agriculture have been completely eliminated using the 2013 horizon. Lastly, domestic farm support has been halved in all scenarios (eliminated in the "free trade" scenario). Liberalisation is limited to agricultural and non-agricultural goods in a first place, and then extend to services. Trade facilitation is introduced in a last stage.

We have been using a two-step approach. In a first step, we have tried to assess the absolute gains to be expected from a successful Round, by using a very detailed disaggregation. The impact of the standard scenario on world welfare is negligible: this 
would be a "Round for nothing", shedding light on the fact that more ambition is compulsory if one aims at positively impacting the growth for the world economy.

Not all regions in the world economy will extract the same gains from the Round. Differences in initial specialisation, in initial domestic protection, and in factor endowment, will lead to contrasted results. The largest gains are reaped by the EFTA, thanks to its own liberalisation in agriculture. Then comes Korea thanks to its own liberalisation in agriculture and to its offensive interests in the NAMA. More generally, Asia is the region that would certainly suffer the most from a collapse of the negotiations, in addition to South Africa. The frequently raised issue regarding Sub Saharan Africa, a victim of the erosion of preferences and of the increase in world food prices, is ascertained here. The loss is not negligible under the standard scenario, but it disappears when trade facilitation is introduced.

In a second step, we have adopted a less detailed decomposition of the world economy in order to run repeated simulations. For each level of ambition, we disentangle the gains associated with agriculture and the NAMA. In the most ambitious scenario, we also identify the contribution of services. This method points to the limited contribution of agriculture to the overall gains as soon as ambition is present. This contradicts the popular view that agriculture is the key issue of the DDA.

These results shed light on the need for negotiators to combine ambition in the liberalisation and a wide coverage of the items negotiated, in order to obtain a balanced outcome in terms of gains and adjustment costs.

But what is even more stimulating is the perspective of achieving a successful round in terms of trade facilitation. When this item of the DDA is taken into account, the gains of scenario B associated with our less ambitious liberalisation in services are more than doubled. This is equivalent, for Sub-Saharan Africa to a doubling official development aid after 2020. Still, the associated investments remain to be financed, an issue that has not been modelled at this stage. Partial evidence however shows that the return on investment is rapid in this case. 


\section{REFERENCES}

Anderson J., Dimaranan B., Francois J., Hertel T., Hoekman B. and Martin W. (2001), The Vost of Rich and Poor Protection to Developing Economies Journal of African Economies, (10):227-257.

Anderson K, Martin W., and Van de Mensbrugghe D. (2006), Would Multilateral trade reform Benefit Sub-Saharan Africa?, World Bank.

Bchir M. H., Fontagné L. and Jean S. (2005), From Bound Duties to Actual Protection : Industrial Liberalisation in the Doha Round, CEPII Working Paper 2005-12..

Bouët A., Bureau J.-C., Decreux Y. and Jean S. (2004), Multilateral Agricultural Trade Liberalization: The Contrasting Fortunes of Developing Countries in the Doha Round, CEPII Working Paper, 2004-18.

Coulibaly S., Fontagné L. (2006), South-South Trade: Geography Matters, Journal of African Studies, forthcoming.

Cline W. (2004), Reducing Poverty, International Economy, (18), 3: . 76-78

Fox A.K., Francois J.F. and Londono-Kent P. (2003), Measuring Border Crossing Costs and their Impact on Trade Flows: The United States-Mexican Trucking Case.

Francois J.F., Martin W. Commercial Policy (2004), Bindings and Market Access. European Economic Review, 48(2) : 665-79.

Francois J., Van Meijl H. and van Tongeren F. (2005), Trade Liberalization in the Doha Development Round, Economic Policy, CEPR, 20(42):349-391.

Hoekman B. (1995), Assessing the General Agreement on Trade in Services, in W. Martin and L. A. Winters, The Uruguay Round and the Developing Countries, World Bank Discussion Paper 307.

Kalirajan K. (2000). Restrictions on Trade in Distribution Services, Productivity Commission Staff Research Paper, AusInfo, Canberra, August.

Kalirajan K., McGuire G., Nguyen-Hong D., and Schuele M. (2000), The Price Impact of Restrictions on Banking Services, in C. Findlay and T. Warren (Eds), Impediments to Trade in Services: Measurement and Policy Implications, Routledge, London and New York, 215-30

Kang J.S. (2000), Price Impact of Restrictions on Maritime Transport Services, in C. Findlay and T. Warren (Eds), Impediments to Trade in Services: Measurement and Policy Implications, Routledge, London and New York, 189-200. 
Kemp S. (2000), Trade in Education Services and the Impacts of Barriers to Trade, in C. Findlay and T. Warren (Eds), Impediments to Trade in Services: Measurement and Policy Implications, Routledge, London and New York, 231-44.

Laird S, Fernandez de Cordoba S., Vanzetti D. (2003), Market Access Proposals for NonAgricultural Products, CREDIT Research Paper 03-08; University of Nottingham.

Lippoldt D, Kowalski P. (2003), The Doha Development Agenda: Welfare Gains from Further Trade Liberalisation with Respect to Tariffs, OECD Trade Directorate, TD/TC/WP(2003)10/FINAL.

McGuire G. (1998), Australia's Restrictions on Trade in Financial Services, Productivity Commission Staff Research Paper, AusInfo, Canberra, November.

McGuire G., Schuele M. (2000), Restrictiveness of International Trade in Banking Services, in C. Findlay and T. Warren (Eds), Impediments to Trade in Services: Measurement and Policy Implications, Routledge, London and New York, 201-14.

Nguyen-Hong D. (2000), Restrictions on Trade in Professional Services, Productivity Commission Staff Research Paper, AusInfo, Canberra, August.

OECD (2002), Business Benefits of Trade Facilitation, TD/TD/WP(2001)21/FINAL.

OECD (2003), Quantitative Assessment of the Benefits of Trade Facilitation, TD/TD/WP(2003)31/FINAL.

Park S.-C. (2002), Measuring Tariff Equivalents in Cross Border Trade in Services, KIEP Working paper 02-15.

Polaski S. (2006), Winners and Losers : Impact of the Doha Round on Developing Countries, Carnegie Endowment for International Peace.

Walkenhorst P, Dihel N. (2002), Bound Tariffs, Unused Protection, and Agricultural Trade Liberalisation. GTAP Conference Paper.

Warren T. (2000a), The Identification of Impediments to Trade and Investment in Telecommunication Services, in C. Findlay and T. Warren (Eds), Impediments to Trade in Services: Measurement and Policy Implications, Routledge, London and New York, 71-84.

WarrenT. (2000b), The Impact on Output of Impediments to Trade and Investment in Telecommunication Services, in C. Findlay and T. Warren (Eds), Impediments to Trade in Services: Measurement and Policy Implications, Routledge, London and New York, 85-100. 
Wilson J.S., Mann C.L. and Otsuki T. (2003), Trade Facilitation and Economic Development: Measuring the Impact. World Bank Policy Research Working Paper 2988.

World Bank. (2003) Realizing the Development Promise of the Doha Agenda. Global Economic Prospects 2004, Washington. 


\section{LIST OF WORKING PAPERS RELEASED BY CEPII ${ }^{17}$}

2006-09 Disparities in Pension Financing in Europe: Economic and Financial Consequences

J. Château

2006-08 Base de données CHELEM-BAL du CEPII

\section{6-08 Base de données CHELEM-BAL du CEPII}

2006-07 Deindustrialisation and the Fear of Relocations in the Industry

H. Boumellassa \& D. Ünal-Kesenci

H. Boulhol

\& L. Fontagné

C. Deubner

2006-06 A Dynamic Perspective for the Reform of the Stability and Gowth Pact

2006-05 China's Emergence and the Reorganisation of Trade Flows in Asia

G. Gaulier, F. Lemoine \& D. Ünal-Kesenci

2006-04 Who Pays China's Bank Restructuring Bill?

G. Ma

G. Gaulier,

2006-03 Structural Determinants of the Exchange-Rate PassThrough

A. Lahrèche-Révil \& I. Méjean

2006-02 Exchange-Rate Pass-Through at the Product Level

2006-01 Je t'aime, moi non plus : Bilateral Opinions and International Trade

G. Gaulier, A. Lahrèche-Révil \& I. Méjean

A.C. Disdier \& T. Mayer

2005-23 World Trade Competitiveness: A Disaggregated View by Shift-Share Analysis

A. Cheptea, G. Gaulier \& S. Zignago

2005-22 Chômage et réformes du marché du travail au Japon

E. Dourille-Feer

2005-21 Profitability of Foreign and Domestic Banks in Central and Eastern Europe: Does the Mode of Entry Matter?

O. Havrylchyk \&

E. Jurzyk

2005-20 ECB Governance in an Enlarged Eurozone

A. Bénassy-Quéré \&

Working papers are circulated free of charge as far as stocks are available; thank you to send your request to CEPII, Sylvie Hurion, 9, rue Georges-Pitard, 75015 Paris, or by fax : (33) 0153685504 or by e-mail sylvie.hurion @ cepii.fr. Also available on: llwww.cepii.fr. Working papers with* are out of print. They can nevertheless be consulted and downloaded from this website.

${ }^{17}$ Les documents de travail sont diffusés gratuitement sur demande dans la mesure des stocks disponibles. Merci d'adresser votre demande au CEPII, Sylvie Hurion, 9, rue Georges-Pitard, 75015 Paris, ou par fax : (33) 0153685504 ou par e-mail sylvie.hurion@ cepii.fr. Egalement disponibles sur : Ilwww.cepii.fr. Les documents de travail comportant* sont épuisés. Ils sont toutefois consultable sur le web CEPII. 
E. Turkisch

2005-19 What Are EU Trade Preferences Worth for Sub-

F. Candau \& S. Jean Saharan Africa and Other Developing Countries?

2005-18 Binding Overhang and Tariff-Cutting Formulas

M.H. Bchir, S. Jean \&

D. Laborde

2005-17 International Trade and Income Distribution: Reconsidering the Evidence

I. Bensidoun, S. Jean \& A. Sztulman

2005-16 China and the Relationship between the Oil Price and the Dollar

A. Bénassy-Quéré, V. Mignon \& A. Penot

S. Jean, D. Laborde \& W. Martin

2005-14 Is Erosion of Tariff Preferences a Serious Concern?

A. Bouët, L. Fontagné \& S. Jean

2005-13 The Consequences of Agricultural Trade Liberalization for Developing Countries: Distinguishing Between Genuine Benefits and False Hopes

2005-12 From Bound Duties to Actual Protection: Industrial Liberalisation in the Doha Round

M.H. Bchir,

L. Fontagné \& S. Jean

2005-11 Impact de l'ouverture financière sur les inégalités internes dans les pays émergents

2005-10 Disentangling Horizontal and Vertical Intra-Industry Trade

A. Bénassy-Quéré \& V. Salins

L. Fontagné, M. Freudenberg \& G. Gaulier

2005-09 China's Integration in East Asia: Production Sharing, FDI \& High-Tech Trade

G. Gaulier, F. Lemoine D. Ünal-Kesenci

2005-08 Tax Competition and Public Input

A. Bénassy-Quéré, N. Gobalraja \&

A. Trannoy

2005-07 Trade Liberalisation, Growth and Poverty in Senegal: A Dynamic Microsimulation CGE Model Analysis

2005-06 Migration, Trade and Wages

2005-05 Institutional Determinants of Foreign Investment

2005-04 L'économie indienne : changements structurels et perspectives à long terme

N. Annabi, F. Cissé, J. Cockburn \&

B. Decaluwé

A. Hijzen \& P. Wright

A. Bénassy-Quéré, M. Coupet \& T. Mayer

S. Chauvin \& F. Lemoine 
2005-03 Programme de travail du CEPII pour 2005

2005-02 Market Access in Global and Regional Trade

T. Mayer \& S. Zignago

2005-01 Real Equilibrium Exchange Rate in China

V. Coudert \&

C. Couharde

2004-22 A Consistent, ad-valorem Equivalent Measure of Applied Protection Across the World: The MAcMapHS6 Database

A. Bouët, Y. Decreux,

L. Fontagné, S. Jean \& D. Laborde

J. Sgard

2004-21 IMF in Theory: Sovereign Debts, Judicialisation and Multilateralism

2004-20 The Impact of Multilateral Liberalisation on European Regions: a CGE Assessment

2004-19 La compétitivité de l'agriculture et des industries agroalimentaires dans le Mercosur et l'Union européenne dans une perspective de libéralisation commerciale

S. Jean \& D. Laborde

N. Mulder, A. Vialou, B. David,

M. Rodriguez \& M. Castilho

2004-18 Multilateral Agricultural Trade Liberalization: The Contrasting Fortunes of Developing Countries in the Doha Round

2004-17 UK in or UK out? A Common Cycle Analysis between the UK and the Euro Zone

2004-16 Regionalism and the Regionalisation of International Trade

G. Gaulier, S. Jean \&

D. Ünal-Kesenci

2004-15 The Stock-Flow Approach to the Real Exchange Rate of CEE Transition Economies

B. Egert,

A. Lahrècche-Révil \&

K. Lommatzsch

2004-14 Vieillissement démographique, épargne et retraite : une analyse à l'aide d'un modèle d'équilibre général à agents hétérogènes

2004-13 Burden Sharing and Exchange-Rate Misalignments within the Group of Twenty

C. Bac \& J. Chateau

A. Bénassy-Quéré, P. Duran-Vigneron, A. Lahrèche-Révil \& V. Mignon

2004-12 Regulation and Wage Premia

S. Jean \& G. Nicoletti

2004-11 The Efficiency of Fiscal Policies: a Survey of the Literature

S. Capet

2004-10 La réforme du marché du travail en Allemagne : les enseignements d'une maquette

S. Capet 
2004-09 Typologie et équivalence des systèmes de retraites

2004-08 South - South Trade: Geography Matters

2004-07 Current Accounts Dynamics in New EU Members: Sustainability and Policy Issues

2004-06 Incertitude radicale et choix du modèle

2004-05 Does Exchange Rate Regime Explain Differences in Economic Results for Asian Countries?

2004-04 Trade in the Triad: How Easy is the Access to Large Markets?

2004-03 Programme de travail du CEPII pour 2004

2004-02 Technology Differences, Institutions and Economic Growth: a Conditional Conditional Convergence

2004-01 Croissance et régimes d'investissement

2003-22 A New Look at the Feldstein-Horioka Puzzle using a Integrated Panel

2003-21 Trade Linkages and Exchange Rates in Asia :The Role of China

2003-20 Economic Implications of Trade Liberalization Under the Doha Round

2003-19 Methodological Tools for SIA - Report of the CEPII Worshop held on 7-8 November 2002 in Brussels

2003-18 Order Flows, Delta Hedging and Exchange Rate Dynamics

2003-17 Tax Competition and Foreign Direct Investment

2003-16 Commerce et transfert de technologies : les cas comparés de la Turquie, de l'Inde et de la Chine

2003-15 The Empirics of Agglomeration and Trade

2003-14 Notional Defined Contribution: A Comparison of the French and German Point Systems

2003-13 How Different is Eastern Europe? Structure and Determinants of Location Choices by French Firms in Eastern and Western Europe
P. Villa

S. Coulibaly \&

L. Fontagné

P. Zanghieri

P. Villa

V. Coudert \&

M. Dubert

L. Fontagné, T. Mayer \& S. Zignago

H. Boulhol

P. Villa

A. Banerjee

P. Zanghieri

A. Bénassy-Quéré \& A. Lahrèche-Révil

J. Francois, H. van Meijl \& F. van Tongeren

B. Rzepkowski

A. Bénassy-Quéré,

L. Fontagné \&

A. Lahrèche-Révil

F. Lemoine \&

D. Ünal-Kesenci

K. Head \& T. Mayer

F. Legros

A.C. Disdier \& T. Mayer 
2003-12 Market Access Liberalisation in the Doha Round: Scenarios and Assessment

2003-11 On the Adequacy of Monetary Arrangements in SubSaharian Africa

2003-10 The Impact of EU Enlargement on Member States: a CGE Approach

2003-09 India in the World Economy: Traditional Specialisations and Technology Niches

2003-08 Imitation Amongst Exchange-Rate Forecasters: Evidence from Survey Data

2003-07 Le Currency Board à travers l'expérience de l'Argentine

2003-06 Trade and Convergence: Revisiting Ben-Davil

2003-05 Estimating the Fundamental Equilibrium Exchange Rate of Central and Eastern European Countries the EMU Enlargement Perspective

2003-04 Skills, Technology and Growth is ICT the Key to Success?

2003-03 L'investissement en TIC aux Etats-Unis et dans quelques pays européens

2003-02 Can Business and Social Networks Explain the Border Effect Puzzle?
L. Fontagné,

J.L. Guérin \& S. Jean

A. Bénassy-Quéré \& M. Coupet

H. Bchir, L. Fontagné \& P. Zanghieri

S. Chauvin \& F. Lemoine

M. Beine,

A. Bénassy-Quéré \&

H. Colas

S. Chauvin \& P. Villa

G. Gaulier

B. Egert \&

A. Lahrèche-Révil

J. Melka, L. Nayman,

S. Zignago \&

N. Mulder

G. Cette \& P.A. Noual

P.P. Combes, M. Lafourcade \& T. Mayer 


\section{CEPII \\ DOCUMENTS DE TRAVAIL / WORKING PAPERS}

Si vous souhaitez recevoir des Documents de travail, merci de remplir le coupon-réponse ci-joint et de le retourner à :

Should you wish to receive copies of the CEPII's Working papers, just fill the reply card and return it to:

Sylvie HURION - Publications

CEPII - 9, rue Georges-Pitard - 75740 Paris - Fax : (33) 1.53.68.55.04

sylvie.hurion@cepii.fr

M./Mme / Mr./Mrs

Nom-Prénom / Name-First name

Titre / Title

Service / Department

Organisme / Organisation

Adresse / Address.

Ville \& CP / City \& post code.

Pays / Country..... Tél.

Your e-mail

Désire recevoir les Document de travail du CEPII $\mathrm{n}^{\circ}$ :

Wish to receive the CEPII's Working Papers No:

Souhaite être placé sur la liste de diffusion permanente (pour les bibliothèques)

Wish to be placed on the standing mailing list (for Libraries). 